Check for updates

Cite this: J. Mater. Chem. C, 2019, 7, 4509

Received 8th February 2019, Accepted 26th February 2019

DOI: $10.1039 / c 9 t c 00747 d$

rsc.li/materials-c

\title{
Highly efficient platinum-based emitters for warm white light emitting diodes $\dagger$
}

\author{
Violeta Sicilia, (D) *a Sara Fuertes, (D) ${ }^{\mathrm{b}}$ Andrés J. Chueca, (D) ${ }^{\mathrm{b}}$ Lorenzo Arnal, (D) $^{\mathrm{b}}$ \\ Antonio Martín, (D) ${ }^{\mathrm{b}}$ Mariano Perálvarez, (D) ${ }^{\mathrm{C}}$ Chiara Botta (D) ${ }^{\mathrm{d}}$ and \\ Umberto Giovanella (iD) ${ }^{d}$
}

\begin{abstract}
New cycloplatinated $\mathrm{N}$-heterocyclic carbene $(\mathrm{NHC})$ compounds with chelate diphosphines $\left(\mathrm{P}^{\wedge} \mathrm{P}\right)$ as ancillary ligands, $\left[\mathrm{Pt}\left(\mathrm{R}-\mathrm{C}^{\wedge} \mathrm{C}^{*}\right)\left(\mathrm{P}^{\wedge} \mathrm{P}\right)\right] \mathrm{PF} \mathrm{F}_{6}\left(\mathrm{R}-\mathrm{C}=\right.$ Naph, $\mathrm{P} \wedge \mathrm{P}=\mathrm{dppm} \mathbf{1 A}$, dppe 2A, dppbz 3A; $\mathrm{R}=\mathrm{CO}_{2} \mathrm{Et}, \mathrm{P} \wedge \mathrm{P}=\operatorname{dppm} \mathbf{1 B}$, dppe 2B, dppbz 3B), have been prepared. Their photophysical properties have been extensively studied and supported by the time-dependent-density functional theory (TD-DFT). These compounds show a great thermal stability and a very efficient blue $\left(\mathrm{CO}_{2} \mathrm{Et}-\mathrm{C}^{\wedge} \mathrm{C}^{\star}\right)$ or cyan $\left(\mathrm{Naph}^{\wedge} \mathrm{C}^{\star}\right)$ emission in PMMA films $(5$ wt\%), with photoluminescence quantum yield (PLQY) ranging from $53 \%$ to $95 \%$. In the solid state, the emission of the $\mathrm{Naph}^{\wedge} \mathrm{C}^{*}$ derivatives becomes orange $(\mathbf{1 A}, \mathbf{2 A})$ or white $(\mathbf{3 A}$, dual blue and yellow emission) due to the operating $\pi-\pi$ intermolecular interactions. We have investigated the potential use of these materials for solid-state lighting (SSL) applications. OLEDs with different architectures containing mixtures of $\mathbf{1 B}$ and $\mathbf{3 A}$ in different ratios as dopants were fabricated. In addition, two-component white light remote phosphors were obtained by stacking different combinations of $\mathbf{1 B}$ or $\mathbf{3 B}$ as the blue emitter with $[\mathrm{Pt}(\mathrm{bzq})(\mathrm{CN})(\mathrm{CNX} \mathrm{Xl})]$ (R) $($ bzq = benzoquinolate, $X y l=2,6$-dimethylphenyl) as the red emitter using a $365 \mathrm{~nm}$ LED as pumping source. By changing the blue: red ratio, warm white light with optimal CRI and $D_{\mathrm{uv}}$ values and a great range of nominal CCT (4000-2000 K) was obtained.
\end{abstract}

\section{Introduction}

With the irruption of LED technology in the lighting arena, different kinds of LED architectures capable of creating white light in an efficient and reliable manner have been developed. ${ }^{1}$ Currently, two types of phosphor-converted white LEDs (pcWLEDs) are commercially available depending on their excitation wavelength. On one hand, there are those based on a blue LED (InGaN) chip coated with a yellow phosphor (e.g. $\mathrm{Y}_{3} \mathrm{Al}_{5} \mathrm{O}_{12}: \mathrm{Ce}^{3+}=$ YAG:Ce). On the other hand are those based on near ultraviolet (NUV) LED

\footnotetext{
${ }^{a}$ Departamento de Química Inorgánica, Escuela de Ingeniería y Arquitectura de Zaragoza, Instituto de Sintesis Química y Catálisis Homogénea (ISQCH), CSIC - Universidad de Zaragoza, Campus Río Ebro, Edificio Torres Quevedo, 50018, Zaragoza, Spain. E-mail: v.sicilia@csic.es

${ }^{b}$ Departamento de Química Inorgánica, Facultad de Ciencias, Instituto de Síntesis Quimica y Catálisis Homogénea (ISQCH), CSIC - Universidad de Zaragoza, Pedro Cerbuna 12, 50009, Zaragoza, Spain ${ }^{c}$ IREC, Catalonia Institute for Energy Research, Jardins de les Dones de Negre 1. PL2, 08930 Sant Adrià de Besòs, Barcelona, Spain

${ }^{d}$ Istituto per lo Studio delle Macromolecole, Consiglio Nazionale delle Ricerche (CNR), Via Corti 12, 20133, Milano, Italy $\dagger$ Electronic supplementary information (ESI) available: General information about procedures and instrumentation, X-ray structure determinations, computational methods, preparation of the PMMA films, LEDs performance and remote phosphor devices' preparation. CCDC 1885174-1885178. For ESI and crystallographic data in CIF or other electronic format see DOI: 10.1039/c9tc00747d
}

pumping coated with a mixture of different phosphors. In both cases white emission is achieved through excitation and subsequent re-emission, but the complexity is bigger in the latter since the blue contribution is also covered by a phosphor. In order to get photo-biologically healthier white light, the key issue in this technology is to minimize the fraction of blue light (around $460 \mathrm{~nm}$ ) which potentially leads to warmer CCTs. ${ }^{1-3}$

There is growing evidence that inadequate light during the day and mainly during the evenings or at night contributes to sleep problems and circadian clock misalignment. ${ }^{4-6}$ Because the melanopsin contained in the retinal ganglion cells (ipRGCs) is photoactivated by $460 \mathrm{~nm}$ blue light, the artificial light striking the retina between dusk and dawn inhibits sleep-promoting neurons in the hypothalamus, and suppresses the nightly release of the soporific hormone melatonin. ${ }^{7,8}$ These factors reduce sleepiness, increase alertness and lead to the development of health problems like obesity, heart disease, depression and neurodegenerative diseases such as Alzheimer's and Parkinson's. 9,10

So, low CCTs, high luminous efficiency (LE) and high color rendering index (CRI) are important characteristics to be considered when fabricating pcWLEDs as environmentally friendly light sources. Also, concerning the chemical composition, the use of rare-earth-based phosphors leads us to foresee a longterm price rise and some logistical problems on the horizon. ${ }^{11}$ In this sense, phosphorescent organometallic transition metal 
complexes (TMCs) have become crucial in the development of electroluminescent devices such as phosphorescent organic light-emitting diodes (PhOLEDs) and white-light-emitting electrochemical cells (LEECS), mostly those of $\operatorname{Ir}(\mathrm{III})^{12-14}$ and Pt(II). ${ }^{15-18}$

Newly developed strategies to achieve efficient white emitting devices have been focused on single-doped WOLEDs using square planar platinum(II) complexes. In these systems, the white light is obtained by combination of blue emission from isolated molecules and orange-red emission from excimers. Controlling the dopant concentration to obtain efficient systems has been successfully accomplished; however, their CRI values are still below $80 .{ }^{19-24}$

The work presented here represents the research of technological alternatives that could improve solid state lighting (SSL) technology in terms of light quality and cost; light quality because we report on systems capable of generating white light with high CRI and low CCT values, and cost because all the compounds reported in this work are $100 \%$ rare-earth-free emitting phosphors. Therefore, keeping with our mastered organometallic approach of using cyclometalated N-heterocyclic carbenes (NHC) as highly efficient emitters to prepare lighting devices, ${ }^{25-27}$ herein we report the synthesis and complete structural and photophysical studies of cycloplatinated NHC compounds with diphosphines $\left(\mathrm{P}^{\wedge} \mathrm{P}\right)$ as auxiliary ligands, $\left[\mathrm{Pt}\left(\mathrm{R}-\mathrm{C}^{\wedge} \mathrm{C}^{*}\right)\left(\mathrm{P}^{\wedge} \mathrm{P}\right)\right] \mathrm{PF}_{6}(\mathrm{R}-\mathrm{C}=\mathrm{Naph}$, $\mathrm{P}^{\wedge} \mathrm{P}=\mathrm{dppm}$ 1A, dppe 2A, dppbz 3A; $\mathrm{R}=\mathrm{CO}_{2} \mathrm{Et}, \mathrm{P}^{\wedge} \mathrm{P}=\mathrm{dppm}$ 1B, dppe 2B, dppbz 3B). Taking into account their emitting features, we used a selection of them as blue (1B, 3B), and orange (1A) emitters for SSL applications: WOLEDs and remote pcWLEDs. The red emitter $([\mathrm{Pt}(\mathrm{bzq})(\mathrm{CN})(\mathrm{CN} t \mathrm{Bu})]$, bzq = benzo[h]-quinoline; $\mathrm{R})$ was used to obtain warm and healthy white light illumination.

\section{Results and discussion}

\subsection{Emissive compounds: synthesis and characterization}

Compounds $\left[\mathrm{Pt}\left(\mathrm{R}-\mathrm{C}^{\wedge} \mathrm{C}^{*}\right)\left(\mathrm{P}^{\wedge} \mathrm{P}\right)\right] \mathrm{PF}_{6}(\mathbf{1 A}-\mathbf{3 A} ; \mathbf{1 B}-\mathbf{3 B}$, see Scheme 1) were prepared in high yields, $86 \% 2 \mathrm{~A}-66 \% 2 \mathrm{~B}$, from the corresponding starting compound $\left[\left\{\mathrm{Pt}(\mu-\mathrm{Cl})\left(\mathrm{R}-\mathrm{C}^{\wedge} \mathrm{C}^{*}\right)\right\}_{2}\right] .{ }^{25,26}$

The most relevant structural information came from multinuclear NMR spectra (see Table 1, Experimental section and ESI $\dagger$ part 2) and the X-ray diffraction study of single crystals of $\mathbf{1 A}, \mathbf{3 A}$, and $\mathbf{1 B}-\mathbf{3 B}$ (see Fig. 1 and $\mathrm{ESI} \dagger$ part 3 for figures, data and discussion).

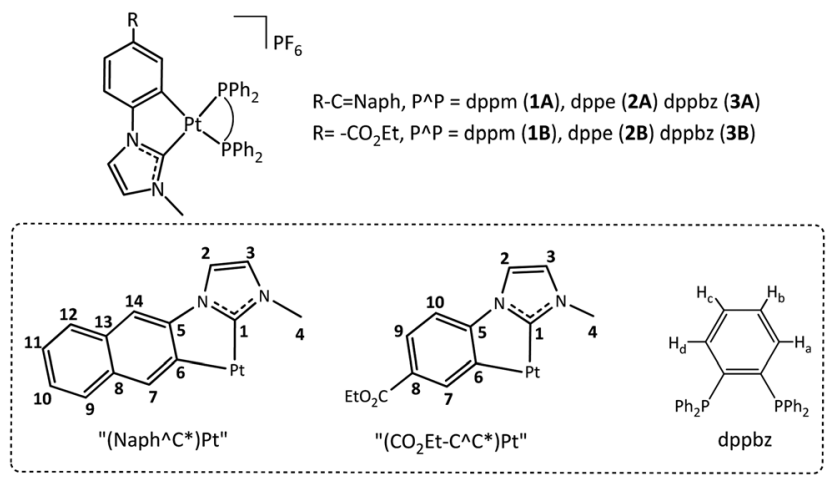

Scheme 1 Scheme of new complexes and numeration for NMR characterization.
Table 1 Relevant ${ }^{31} \mathrm{P}\left\{{ }^{1} \mathrm{H}\right\}^{a}$ and ${ }^{195} \mathrm{Pt}\left\{{ }^{1} \mathrm{H}\right\}^{b}$ NMR data $(\delta(\mathrm{ppm}), \mathrm{J}(\mathrm{Hz}))$

\begin{tabular}{llllllr}
\hline & $\delta \mathrm{Pt}$ & ${ }^{1} J_{\mathrm{Pt}, \mathrm{P} \text { trans-C1 }}$ & ${ }^{1} J_{\mathrm{Pt}, \mathrm{P} \text { trans-C6 }}$ & $\delta \mathrm{P}_{\text {trans-C1 }}$ & $\delta \mathrm{P}_{\text {trans-C6 }}$ & $J_{\mathrm{P}, \mathrm{P}}$ \\
\hline 1A & 4384.0 & 2398.6 & 1526.1 & $-36.9 \nu_{\mathrm{A}}$ & $-37.5 \nu_{\mathrm{B}}$ & 39.8 \\
2A & 4991.0 & 2715.1 & 1925.9 & 50.6 & 43.6 & 6.0 \\
3A & 4906.0 & 2671.6 & 1915.4 & 47.6 & 39.3 & 4.1 \\
1B & 4411.8 & 2378.4 & 1556.7 & $-37.9 \nu_{\mathrm{A}}$ & $-38.3 \nu_{\mathrm{B}}$ & 40.3 \\
2B & 5013.7 & 2706.5 & 1958.5 & 50.6 & 43.6 & 6.2 \\
3B & 4955.8 & 2670.4 & 1950.8 & 47.7 & 40.5 & 4.7 \\
\multicolumn{2}{c}{${ }^{2} 162 \mathrm{MHz}, \mathrm{CD}_{2} \mathrm{Cl}_{2} .{ }^{b} 86 \mathrm{MHz}, \mathrm{CD}_{2} \mathrm{Cl}_{2}}$. & & & \\
\end{tabular}
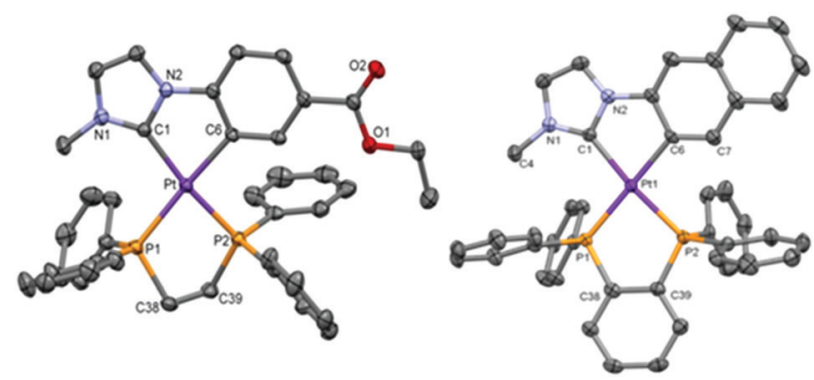

Fig. 1 Molecular structures of the cationic complexes for $\mathbf{2 B}$ (left) and $\mathbf{3 A}$ (right). Thermal ellipsoids are drawn at the $50 \%$ probability level. Hydrogen atoms, $\mathrm{PF}_{6}$ and solvent molecules have been omitted for clarity.

The two inequivalent $\mathrm{P}$ atoms of the dppm derivatives $(\mathbf{1 A} / \mathbf{1 B})$ (Table 1 and Fig. S1 for 1B, ESI $\dagger$ ) appear upfield shifted with respect to that of free $\operatorname{dppm}(\delta=-23.8 \mathrm{ppm})^{28}$ as an $\mathrm{AB}$ system $\left(J_{\mathrm{P}, \mathrm{P}} \sim 40 \mathrm{~Hz}\right)$. However, those for the dppe in $\mathbf{2 A} / \mathbf{2 B}$ and dppbz in 3A/3B (Fig. S2 for 2A, ESI $\dagger$ ) appear downfield shifted with respect to that of the corresponding free diphosphine (dppe $=$ $-12.5 \mathrm{ppm}, \mathrm{dppbz}=-13.8 \mathrm{ppm})^{28}$ as AX systems with $J_{\mathrm{P}, \mathrm{P}}$ values of about $5 \mathrm{~Hz} \cdot{ }^{29}$ Every ${ }^{31} \mathrm{P}$ signal appears flanked by two sets of ${ }^{195} \mathrm{Pt}$ satellites. The larger ${ }^{1} J_{\mathrm{Pt}, \mathrm{P}}$ value corresponds to the $\mathrm{P}$ atom located trans to the N-heterocyclic carbene (C1), whose trans influence is smaller than that of the aromatic $\mathrm{C}$ atom (C6). ${ }^{30}$ The ${ }^{195} \mathrm{Pt}\left\{{ }^{1} \mathrm{H}\right\}$ NMR spectrum of each compound shows a doublet of doublets due to the coupling of the Pt center to two inequivalent $\mathrm{P}$ atoms (see Fig. S3, ESI $\dagger$ and Table 1). It is worth noting the downfield shift of the ${ }^{195} \mathrm{Pt}$ resonances of the dppm complexes $(\mathbf{1 A} / \mathbf{1 B})$ when compared to those of the dppe (2A/2B) and dppbz ( $\mathbf{3 A} / \mathbf{3} \mathbf{B})$ counterparts, which can be attributed to the great strain in the 4-membered ring. ${ }^{28,29}$

Thermo-gravimetric analyses (TGA) of all compounds indicate that they are stable under an argon atmosphere at $1 \mathrm{~atm}$ over $350{ }^{\circ} \mathrm{C}\left(368.21{ }^{\circ} \mathrm{C} 1 \mathrm{~A}, 383.40{ }^{\circ} \mathrm{C} 2 \mathrm{~A}, 399.83{ }^{\circ} \mathrm{C} 3 \mathrm{~A}, 350.72{ }^{\circ} \mathrm{C}\right.$ 1B, $350.31{ }^{\circ} \mathrm{C} 2 \mathrm{~B}$ and $\left.381.13{ }^{\circ} \mathrm{C} 3 \mathrm{~B}\right)$.

\subsection{Photophysical properties and theoretical calculations}

Absorption properties and TD-DFT calculations. The lowest energy absorption of $\mathbf{1 A - 3 A}$ in $\mathrm{CH}_{2} \mathrm{Cl}_{2}\left(5 \times 10^{-5} \mathrm{M}\right)$ appears at $\lambda \geq$ $350 \mathrm{~nm}$, at lower energies than those of 1B-3B (ca. $320 \mathrm{~nm}$, Fig. 2 and ESI $\dagger$ part 4), as previously stated. ${ }^{26,27}$ On the other hand, the low energy bands of the dppm derivatives (1A and 1B) appear red shifted with respect to the corresponding dppe and dppbz ones (2A, 2B and 3A, 3B), indicating that both $\mathrm{R}^{-} \mathrm{C}^{\wedge} \mathrm{C}^{*}$ and $\mathrm{P}^{\wedge} \mathrm{P}$ ligands are involved in the lowest energy spin-allowed transition. 

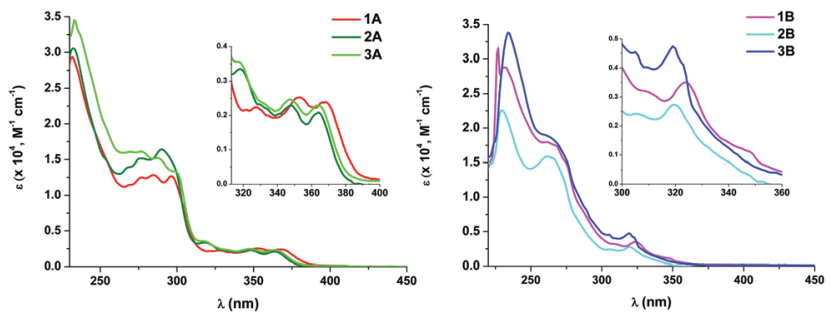

Fig. 2 UV-Vis absorption spectra of $1 \mathrm{~A}-3 \mathrm{~A}$ (left) and $\mathbf{1 B}-\mathbf{3 B}$ (right) in $\mathrm{CH}_{2} \mathrm{Cl}_{2}$ $\left(5 \times 10^{-5} \mathrm{M}\right)$. Insets: Expanded views of the lower-energy absorptions.

These absorptions obey Beer's law in the range $10^{-3}-10^{-6} \mathrm{M}$ in $\mathrm{CH}_{2} \mathrm{Cl}_{2}$, in agreement with the absence of significant aggregation in this concentration range. ${ }^{31}$ The absorption spectra of powdered samples of $\mathbf{1 A}-\mathbf{3 A}$ and $\mathbf{1 B}-\mathbf{3 B}$ (ESI $\dagger$ part 4) appear quite similar to those observed in solutions of $\mathrm{CH}_{2} \mathrm{Cl}_{2}$. Therefore, the same origin of the lowest energy absorptions can be assumed.

Theoretical calculations (DFT and TD-DFT) were carried out on the cations of $\mathbf{1 A}, \mathbf{3 A}, \mathbf{1 B}$ and $\mathbf{3 B}$ (see ESI $\dagger$ part 5 for tables, figures and discussion). Considering that in each case, the calculated spin-allowed transition $\left(\mathrm{S}_{1}\right)$ fits well with the lowest energy absorption and that the main contribution to it is the HOMO to LUMO transition, the origin of this absorption can be ascribed to mixed $\mathrm{LL}^{\prime} \mathrm{CT}\left[\pi(\mathrm{NHC}) \rightarrow \pi^{*}\left(\mathrm{P}^{\wedge} \mathrm{P}\right)\right] / \mathrm{LMCT}[\pi(\mathrm{NHC}) \rightarrow$ $5 \mathrm{~d}(\mathrm{Pt})] / \mathrm{ILCT}\left[\pi(\mathrm{NHC}) \rightarrow \pi^{*}(\mathrm{NHC})\right]$ transitions for the $\mathrm{Naph}^{\wedge} \mathrm{C}^{*}$ derivatives (1A and 3A), and to $\mathrm{LL}^{\prime} \mathrm{CT}\left[\pi(\mathrm{NHC}) \rightarrow \pi^{*}\left(\mathrm{P}^{\wedge} \mathrm{P}\right)\right] / \mathrm{ILCT}$

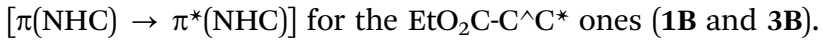

Emission properties. Emission data for 1A-3A and 1B-3B are summarized in Table S10 (ESI $\dagger$ part 6). In a rigid matrix of $\mathrm{CH}_{2} \mathrm{Cl}_{2}\left(10^{-5} \mathrm{M} ; 77 \mathrm{~K}\right)$ and in poly(methyl methacrylate) (PMMA) films (5 wt\% doped), all complexes show blue and highly structured emissions with vibronic spacings $\left(\sim 1474 \mathrm{~cm}^{-1}\right.$, corresponding to the $\mathrm{C}=\mathrm{C} / \mathrm{C}=\mathrm{N}$ stretches of the cyclometalated NHC ligands) at $\lambda \sim 470 \mathrm{~nm}$ for $1 \mathrm{~A}-3 \mathrm{~A}$ or $450-464 \mathrm{~nm}$ for 1B-3B (see Fig. 3 for $\mathbf{1 A}$ and 1B). The corresponding decays are monoexponential with slower decay time (286-563 $\mu \mathrm{s})$ for 1A-3A and faster $(\sim 20 \mu \mathrm{s})$ for $\mathbf{1 B}-\mathbf{3 B}$, indicative of triplet state emissions. These values are in agreement with those observed for other compounds containing these same " $\left(\mathrm{R}-\mathrm{C}^{\wedge} \mathrm{C}^{*}\right) \mathrm{Pt}$ " $(\mathrm{R}-\mathrm{C}=\mathrm{Naph}$, $\mathrm{R}=\mathrm{CO}_{2} \mathrm{Et}$ ) moieties. ${ }^{26,27,30}$

Contrary to what has been observed throughout the UV-vis absorption and TD-DFT sections, the emission energy of the $\mathrm{Naph}^{\wedge} \mathrm{C}^{*}$ derivatives $(\mathbf{1 A - 3 A})$ does not depend on the $\mathrm{P}^{\wedge} \mathrm{P}$ ligand, whereas those of their $\mathbf{B}(\mathbf{1 B}-\mathbf{3 B})$ counterparts clearly
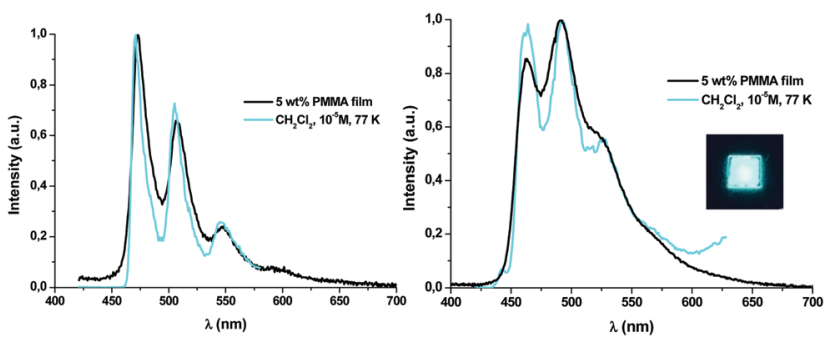

Fig. 3 Normalized emission spectra of $\mathbf{1 A}$ (left) and $\mathbf{1 B}$ (right) upon excitation with UV light. Picture under UV light $(365 \mathrm{~nm})$.

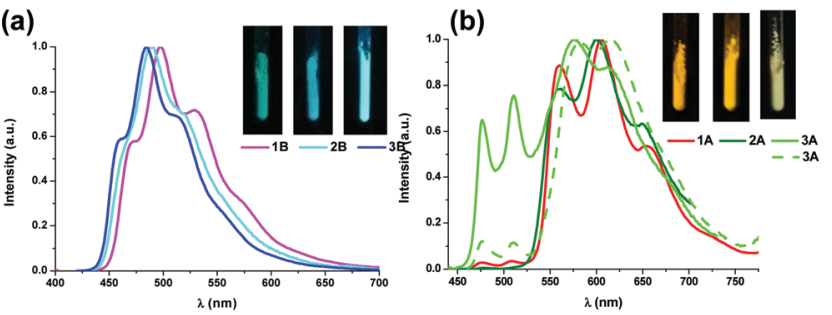

Fig. 4 Normalized emission spectra of 1B-3B (a) and $1 \mathbf{A}-\mathbf{3 A}(\mathrm{b})$ in the solid state at r.t. $\left(-, \lambda_{\mathrm{ex}}=375 \mathrm{~nm}\right.$ and,$- \lambda_{\mathrm{ex}}=400 \mathrm{~nm}$, for $\left.3 \mathrm{~A}\right)$. Pictures under UV light (365 $\mathrm{nm})$.

do (see Fig. S12, ESI $\dagger$ ). This relationship, together with the observed difference in their emission lifetimes, suggests that emissions of the $\mathbf{A}$ and $\mathbf{B}$ derivatives arise from different kinds of excited states. Considering the TD-DFT calculations, these phosphorescent emissions can be assigned mainly to the ${ }^{3}$ ILCT $\left[\pi(\mathrm{NHC}) \rightarrow \pi^{*}(\mathrm{NHC})\right]$ excited state for $\mathbf{1 A}-\mathbf{3 A}$ and to mixed ${ }^{3} \mathrm{LL}^{\prime} \mathrm{CT}\left[\pi(\mathrm{NHC}) \rightarrow \pi^{*}\left(\mathrm{P}^{\wedge} \mathrm{P}\right)\right] /{ }^{3} \mathrm{ILCT}\left[\pi(\mathrm{NHC}) \rightarrow \pi^{*}(\mathrm{NHC})\right]$ transitions for 1B-3B. At higher concentration $\left(10^{-3} \mathrm{M}\right)$ in $\mathrm{CH}_{2} \mathrm{Cl}_{2}$ at $77 \mathrm{~K}$ or in the solid state, the emissions of compounds $\mathbf{1 B}-\mathbf{3 B}$ (see Fig. 4a and Table S10, ESI $\dagger$ ) do not differ much from those obtained in diluted solution $\left(\mathrm{CH}_{2} \mathrm{Cl}_{2} 10^{-5} \mathrm{M}, 77 \mathrm{~K}\right)$. Differently, compounds $\mathbf{1 A}-\mathbf{3 A}$, at higher concentration in $\mathrm{CH}_{2} \mathrm{Cl}_{2}\left(10^{-3} \mathrm{M}\right)$, display wavelength-dependent emissions (see Table S10, ESI $\dagger$ ), similarly to those observed in the related complexes $\left[\left(\mathrm{Naph}^{\wedge} \mathrm{C}^{*}\right) \mathrm{Pt}\left(\mathrm{CNR}^{\prime}\right)_{2}\right] \mathrm{PF}_{6}\left(\mathrm{R}^{\prime}=t\right.$-Bu, Xyl $) .{ }^{26}$ Upon excitation at $\lambda_{\mathrm{ex}} \leq 380 \mathrm{~nm}$, they show a high energy (HE) emission band identical to the one observed in diluted solution. At longer excitation wavelengths $\left(\lambda_{\mathrm{ex}} \sim 400 \mathrm{~nm}\right)$, the intensity of the $\mathrm{HE}$ band decreases and a low energy (LE) emission band with a maximum at ca. $565 \mathrm{~nm}$ becomes dominant (Fig. S13 for 1A, ESI $\dagger$ ). The LE emission fits the main one observed in powdered samples of 1A-3A upon excitation in the range $360-375 \mathrm{~nm}$ (see Fig. 4b). For these solid samples, just in compound $\mathbf{3 A}$, a significant contribution of the HE emission is also observed, but the LE band can be obtained upon selective excitation at longer wavelengths (400 nm). This structured LE band, which exhibits shorter lifetime $(\leq 100 \mu \mathrm{s})$ and a red-shifted excitation profile compared to those of the HE band, can be tentatively assigned to ${ }^{3} \pi \pi^{*}$ transitions, due to the formation of aggregates in the ground state as supported by the X-ray diffraction studies.

Photoluminescence (PL) quantum yield $(\Phi)$ measurements in PMMA films revealed that all complexes are very good emitters at room temperature (QY ranging from 53\% to 95\%) and are amongst the most efficient blue and green-cyan emitters of platinum(II) in PMMA film: $\left[\mathrm{Pt}\left(\mathrm{C}^{\wedge} \mathrm{C}^{*}\right)(\mathrm{acac})\right]\left(\Phi=0.86,{ }^{32} 0.90,{ }^{33}\right)$, $\left[\mathrm{Pt}\left(\mathrm{C}^{* \wedge} \mathrm{C}^{\wedge} \mathrm{C}^{*}\right) \mathrm{Cl}\right]\left(\Phi=0.32^{34}\right)$ and $\left[\mathrm{Pt}\left(\mathrm{C}^{\wedge} \mathrm{X}-\mathrm{L}^{\wedge} \mathrm{L}^{\prime}\right)\right]\left[\mathrm{C}^{\wedge} \mathrm{X}=\right.$ phenyl methyl imidazole; $\mathrm{L}^{\wedge} \mathrm{L}^{\prime}=$ phenoxy pyridine, $\Phi=0.58 ; \mathrm{L}^{\wedge} \mathrm{L}^{\prime}=$ carbazolyl pyridine, $\Phi=0.89 ; \mathrm{C}^{\wedge} \mathrm{X}=$ phenyl pyrazole; $\mathrm{L}^{\wedge} \mathrm{L}^{\prime}=$ carbazolyl pyridine, $\Phi=0.85]^{35}$

\subsection{Device performance and characteristics}

In light of the observed quantum efficiency and thermal stability of these compounds, their great potential to be incorporated as 
emitting centers within a SSL-based architecture for white light generation becomes clear, in our case for OLEDs and remote phosphor-based devices.

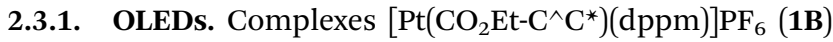
and $\left[\mathrm{Pt}\left(\mathrm{Naph}^{\wedge} \mathrm{C}^{*}\right)(\mathrm{dppbz})\right] \mathrm{PF}_{6}(\mathbf{3 A})$ were chosen as blue and yellowish-orange emitters respectively for the fabrication of solution processed OLEDs. First of all, we built OLEDs containing 1B or 3A as emitters, to optimize the operating conditions for each of them (see ESI, $\dagger$ part 7, Fig. S14 and S15 for devices OL1-OL3 and L1-L9).

With a view to achieving white electroluminescence, by exploiting blue emission from 1A and green-orange emissions from 3A, devices with emissive layer (EML) containing the two dopants with different formulations were manufactured with basic and advanced architectures (see Table 2 and Fig. 5 left).

Devices L10-L12 were built with the ITO/MoO $/ \mathrm{EML} / \mathrm{TPBi} /$ $\mathrm{Ba} / \mathrm{Al}$ configuration. The EL spectrum of $\mathbf{L 1 0}$ (see Fig. 5), with a content of $3 \mathbf{A}: 1 \mathbf{B}$ in the ratio of $10: 10 \mathrm{wt} \%$, shows a main emission from 3A (LE band) with very weak contributions of PVK and 1B. The white light produced has a very appealing warm temperature of $2592 \mathrm{~K}$, within the Planckian locus (see Fig. 6 and Table 2), but the small contribution of the blue components renders a rather poor CRI (65.8). The increase of the amount of the blue emitter, 1B, in L11 (15 wt\%) and L12 (20 wt\%) does not improve the colorimetric or photometric data with respect to those of $\mathbf{L 1 0}$ (see Table 2 and Fig. S16 in the $\mathrm{ESI} \dagger)$.

For devices L13-L15, PBD was replaced by 1,3-bis(5-(4-(tertbutyl)phenyl)-1,3,4-oxadiazol-2-yl)benzene (OXD-7, HOMO = $-6.5 \mathrm{eV}$; LUMO $=-2.8 \mathrm{eV}$ ), as a further optimization step (Fig. 5 left). The EL spectrum (see Fig. 5 right) reveals that the blue emission arising from 1B becomes more relevant

Table 2 EML composition, EQE and lighting parameters ${ }^{a}$ of L10-L15

\begin{tabular}{|c|c|c|c|c|c|c|c|c|}
\hline & 3A:1B & $\begin{array}{l}\text { HTL } \\
(\%)\end{array}$ & $\begin{array}{l}\text { ETL } \\
(\%)\end{array}$ & $\begin{array}{l}\mathrm{EQE}_{\max } \\
(\%)[V]\end{array}$ & CRI & CCT & $\operatorname{CIE}(x, y)$ & $D_{\mathrm{uv}}$ \\
\hline L10 & $10 / 10$ & 57 & 23 & $0.32[11]$ & 65.8 & 2592 & $0.47,0.41$ & 0.0004 \\
\hline L11 & $10 / 15$ & 52.5 & 22.5 & $0.1[8]$ & 72.0 & 2745 & $0.47,0.44$ & 0.0090 \\
\hline L12 & $10 / 20$ & 49 & 21 & 0.05 [9] & 72.0 & 2723 & $0.48,0.44$ & 0.0098 \\
\hline L13 & $10 / 10$ & 57 & 23 & $0.2[14]$ & 75.7 & 5281 & $0.34,0.41$ & 0.0298 \\
\hline L14 & $10 / 5$ & 59.5 & 25.5 & $0.125[13]$ & 76.8 & 4055 & $0.39,0.44$ & 0.0306 \\
\hline L15 & $15 / 5$ & 56 & 24 & 0.15 [12] & 74.8 & 3326 & $0.44,0.45$ & 0.0230 \\
\hline
\end{tabular}

${ }^{a}$ Obtained at $12 \mathrm{~V}(\mathbf{L 1 0}-\mathbf{L 1 2})$ and $10 \mathrm{~V}(\mathbf{L 1 3}-\mathbf{L 1 5})$.
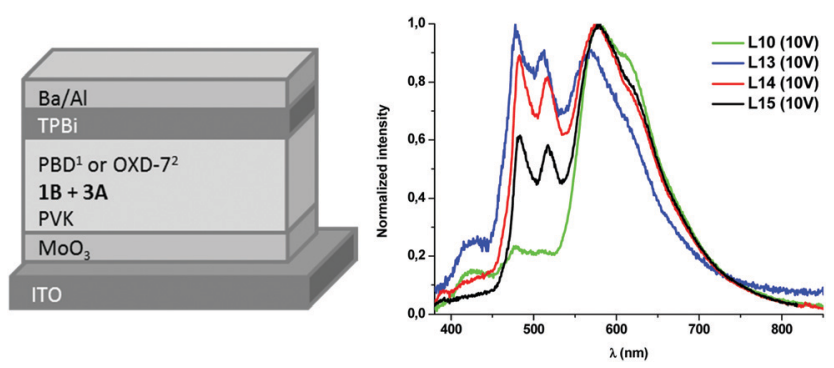

Fig. 5 (left) Device architectures of white OLEDs: ${ }^{1}$ L10-L12; ${ }^{2}$ L13-L15 (right) EL spectra at $10 \mathrm{~V}$ of L10, L13-L15.
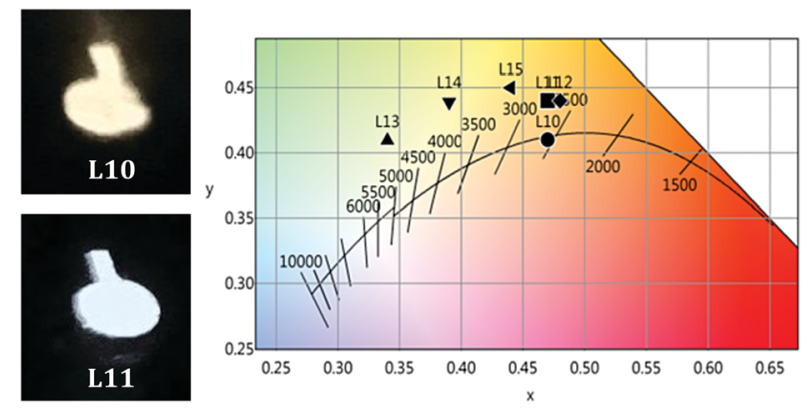

Fig. 6 (left) Pictures of working devices; (right) CIE 1931 diagram of L10-L15.

thanks to the slightly different energy levels of OXD-7 with respect to $\mathrm{PBD}$. However, there is still a big contribution of the LE band of $\mathbf{3 A}$, increasing as the ratio $\mathbf{3 A : 1 B}$ increases from $2: 1$ (L14) to $3: 1$ (L15). As a result, a warmer white light and CRI in the range of 74.8-76.8 were observed.

White OLEDs switch on at about 5-7 V (Fig. S17 in the ESI $\dagger$ ), probably due to the aforementioned high potential barriers for charge injection, mainly for holes, that should be further reduced by interfacial engineering. At high current density the maximum luminance recorded is in the range of $50-250 \mathrm{~cd} \mathrm{~m}^{-2}$ depending on EML formulations and device architectures. The combined highest EQE $(0.2 \%)$ and better CIE $(0.34 ; 0.41)$ and CRI (75.7) were achieved for device L13. As has already been reported for this type of devices, ${ }^{36,37}$ a moderate efficiency rolloff (Fig. S18 in the ESI $\dagger$ ) due to triplet-triplet annihilation, typical of long-lived excited triplet states, cannot be avoided.

2.3.2. Remote phosphor devices. To achieve the high quality CCT and CRI values required in devices for indoor solid-state lighting applications, as stated in the ANSI C8-78.377-2008/2015 for commercial light sources, combination of the luminescence from different phosphors was required; complexes $\mathbf{1 B}$ and $\mathbf{3 B}$ were selected as blue-, $\mathbf{1 A}$ as orange- and $[\mathrm{Pt}(\mathrm{bzq})(\mathrm{CN})(\mathrm{CNXyl})]$ $(\mathbf{R})^{38}$ as red-emitting materials. Several remote phosphor devices with two-component architectures (D1-D10) were prepared by sequential deposition of individual suspensions of the active materials on common glass disks by screen-printing. The relative amount (number of layers) of each phosphor was varied to control the final photometric and colorimetric parameters of these devices (see Table 3 and ESI $\nmid$ part 7). Once a phosphor disk was prepared, it was studied under $365 \mathrm{~nm}$ UV LED light illumination. To do that, the disk was introduced in the holder structure shown in Fig. 7 with the coating facing the pump source. On the other hand, it is worth noting that phosphor stacks were constructed by placing the phosphor with the higher radiative transition close to the glass, so the re-absorption of photons with lower energies from previous layers within the stacks is minimized. In this configuration, we ensured that the outcoming visible light is efficiently transmitted to the analysis stage. Photometric and colorimetric parameters corresponding to D1-D10 can be seen in Table 3 and Fig. 8.

Devices D1 and D2, both containing compound 1A as the warm component, present rather low CRI and non-convenient 
Table 3 Performance of remote phosphor devices D1-D10

\begin{tabular}{|c|c|c|c|c|c|c|c|c|}
\hline Devices (components) & $\mathrm{CRI}^{a}$ & $\mathrm{CCT}^{b}$ & $D_{\mathrm{uv}}$ & $\mathrm{LF}^{c}(\mathrm{mlm})$ & $\operatorname{LER}^{d}\left(\operatorname{lm~} \mathrm{W}^{-1}\right)$ & $\mathrm{LE}^{e}\left(\operatorname{lm} \mathrm{W}^{-1}\right)$ & $\mathrm{WPE}^{f}(\%)$ & CIE $1931(x, y)^{g}$ \\
\hline $\mathbf{D} 2_{(3 \mathrm{~B} / \mathbf{1 A})}$ & 62.4 & 3586 & 0.015 & 242.9 & 360.4 & 0.88 & 0.45 & $0.4158,0.4313$ \\
\hline $\mathbf{D 5}(3 \mathbf{B} / \mathbf{R})$ & 83.6 & 3706 & 0.0057 & 179.6 & 227.9 & 0.65 & 1.53 & $0.3894,0.3700$ \\
\hline $\mathbf{D 6}_{(3 \mathrm{~B} / \mathrm{R})}$ & 81.7 & 3938 & 0.0024 & 214.1 & 228.7 & 0.78 & 1.18 & $0.3815,0.3722$ \\
\hline D7 $(3 \mathbf{B} / \mathbf{R})$ & 85.7 & 1918 & 0.00097 & 140.6 & 209.9 & 0.51 & 0.46 & $0.5380,0.4146$ \\
\hline $\operatorname{D10}_{(1 \mathrm{~B} / \mathrm{R})}$ & 90.2 & 3355 & 0.0064 & 168.1 & 247.9 & 0.61 & 1.44 & $0.4214,0.4138$ \\
\hline
\end{tabular}

${ }^{a}$ Color rendering index. ${ }^{b}$ Correlated color temperature. ${ }^{c}$ Luminous flux. ${ }^{d}$ Luminous efficacy of the radiation. ${ }^{e}$ Luminous efficacy. ${ }^{f}$ Wall-plug efficiency. ${ }^{g}$ CIE coordinates.

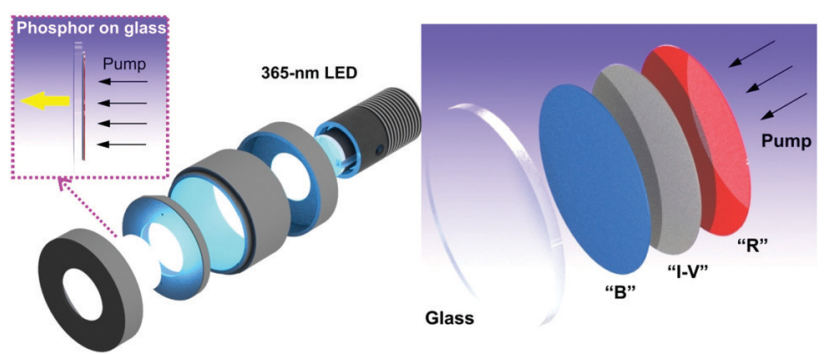

(a)

(b)

Fig. 7 (a) Exploded view of the sample holder used to pump the phosphors and coupling of the resulting emission into the integrating sphere. (b) Schematic drawing of the phosphor stacks $(I-V=$ ink vehicle; $B=$ blue phosphor; $\mathrm{R}=$ red phosphor).

high LER values, ${ }^{39}$ the latter attributed to the excessive overlay of the emission bands of the cool (1B, 3B) and warm (1A) components, resulting in an increase of the intensity at the green region of the visible spectrum (Fig. S19, ESI $\dagger$ ). Also the CIE coordinates reveal that D1 and D2 are not suitable in the current configuration for white light applications, since they are far from the ideal Planckian locus $\left(\left|D_{\mathrm{uv}}\right|>0.006\right)$ (Table 3 and Fig. 8).

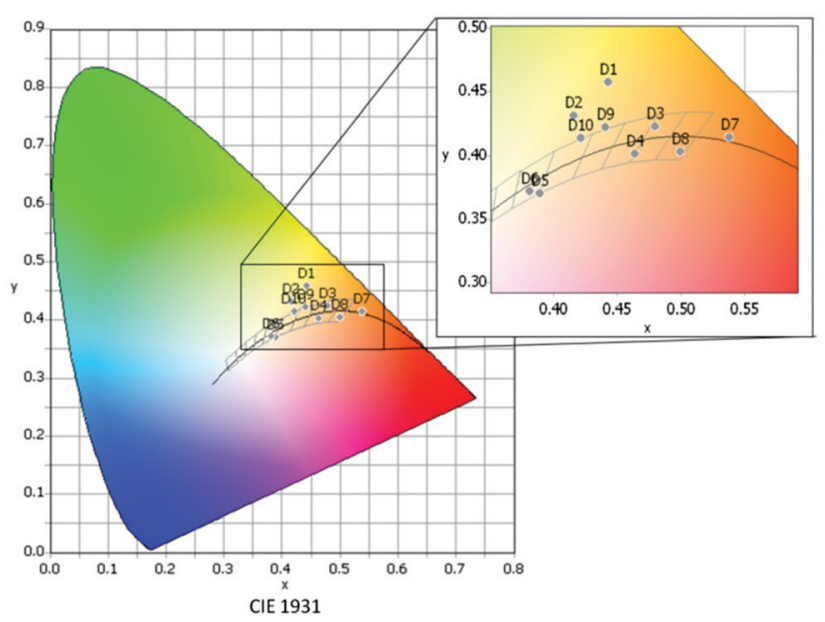

Fig. 8 Distribution of the different devices in the CIE 1931 color space according to their respective color coordinates D1-D10.
To solve these problems, $\mathbf{1 A}$ was substituted by the redemitter [Pt(bzq)(CN)(CNXyl)] (R), ${ }^{39}$ with a less pronounced overlay of the emission band with those of 1B and 3B. Comparison of devices D3 and D4, which just differ in the nature of the blue phosphor (1B in D3, 3B in D4), seems to indicate that both 1B and $\mathbf{3 B}$, combined with the $\mathbf{R}$ component in a $2: 1$ ratio, lead to devices with very similar photometric and colorimetric parameters. In both cases, these have excellent CRI values $(94.3,92.5)$ and CIE coordinates along the Planckian locus $\left(\left|D_{\mathrm{uv}}\right|<0.006\right)$. The spectral shape of devices D3 and $\mathbf{D} 4$ resembles that obtained from incandescent lamps (CRI 100) (Fig. 9 top). An increase of the blue: red ratio to $3: 1$ or $4: 1$ leads to a much colder light. The 3B-containing devices (CCT $=3706 \mathrm{~K}$ D5, $3938 \mathrm{~K}$ D6) show colder light and lower CRI values ( $c a .83)$ than those of the 1B-containing ones (3078 K D9, $3355 \mathrm{~K}$ D10, CRI > 90) but for all of them, the CIE coordinates are along the Planckian locus $\left(\left|D_{\mathrm{uv}}\right|<0.006\right)$.
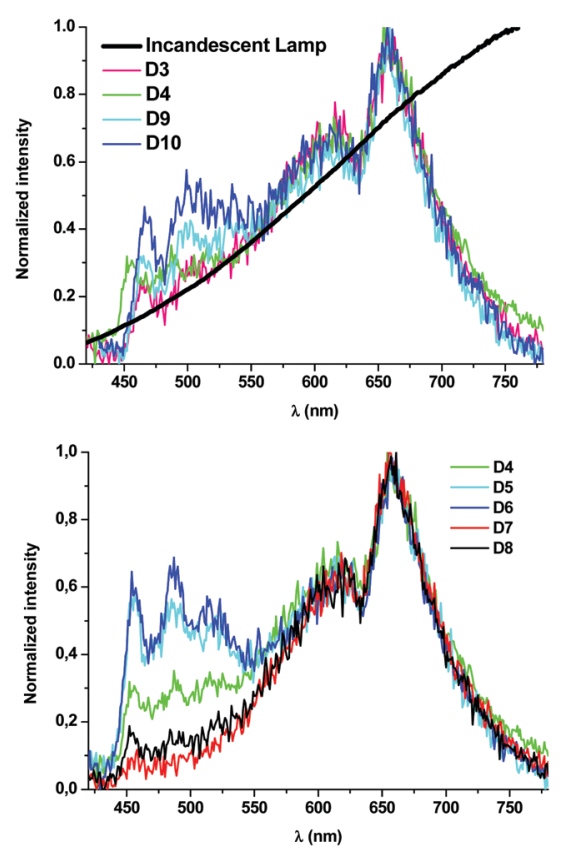

Fig. 9 Normalized emission spectra of devices D3, D4, D9 and D10 and a typical incandescent lamp in the visible region of the spectrum (top) and devices D4-D8 (bottom). 
If we compare those devices (D4-D8) containing the same active components, 3B as blue and $\mathbf{R}$ as red, it seems clear that modifications in the relative number of layers of each phosphor $(3 \mathbf{B}: \mathbf{R}$ ratio: 0.5 : $1 \mathrm{D} 7,0.66: 1 \mathrm{D} 8,2: 1 \mathrm{D} 4,3: 1 \mathrm{D} 5,4: 1 \mathrm{D6})$ lead to a fine control of the CCT values (Fig. 9 bottom) with no dramatic change in the rest of the parameters. In light of the above sequence, it becomes clear that the amount of $\mathbf{R}$ contributes to making the emission warmer; it is possible to achieve devices with high CRI (81.7-92.5), CCT values ranging from $1918 \mathrm{~K}$ (D7) to $3938 \mathrm{~K}$ (D6) and CIE coordinates along the Planckian locus $\left(\left|D_{\mathrm{uv}}\right| \sim 0.00097-0.0057\right)$.

Therefore, this approach allows the fabrication of devices with a great range of nominal CCT values: $4000 \mathrm{~K}$ (D6), $3500 \mathrm{~K}$ (D5 and D10), $3000 \mathrm{~K}$ (D9) and almost $2600 \mathrm{~K}$ (D3 and D4), and opens the gate to even very- or ultrawarm devices (D7 and D8) operating in the "firelight" range of CCTs (1918 K D7 and 2176 K D8), ${ }^{40}$ in all cases within optimal CRI and $D_{\mathrm{uv}}$ values, ${ }^{41}$ that are far more superior than those reported as warm white light LEDs. ${ }^{42-46}$

\section{Conclusions}

New cycloplatinated N-heterocyclic carbene (NHC) compounds with chelate diphosphines $\left(\mathrm{P}^{\wedge} \mathrm{P}\right)$ as ancillary ligands, $\left[\mathrm{Pt}\left(\mathrm{R}-\mathrm{C}^{\wedge} \mathrm{C}^{*}\right)\right.$ $\left.\left(\mathrm{P}^{\wedge} \mathrm{P}\right)\right] \mathrm{PF}_{6}\left(\mathrm{R}-\mathrm{C}=\mathrm{Naph}, \mathrm{CO}_{2} \mathrm{Et} ; \mathrm{P}^{\wedge} \mathrm{P}=\mathrm{dppm}\right.$, dppe, dppbz), were prepared from their corresponding starting materials, $\left[\left\{\mathrm{Pt}\left(\mathrm{R}-\mathrm{C}^{\wedge} \mathrm{C}^{*}\right)\right.\right.$ $\left.(\mu-C l)\}_{2}\right]$. The presence of two chelate ligands $\left(\mathrm{C}^{\wedge} \mathrm{C}^{*}\right.$ and $\left.\mathrm{P}^{\wedge} \mathrm{P}\right)$ in these complexes confers them great robustness and thermal stability.

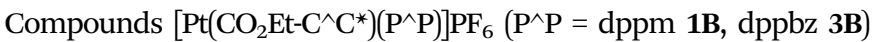
and $\left[\mathrm{Pt}\left(\mathrm{Naph}^{\wedge} \mathrm{C}^{*}\right)(\mathrm{dppbz})\right] \mathrm{PF}_{6}(\mathbf{3 A})$ were selected for fabrication of white light-emitting devices because of their emitting features and high PLQY in PMMA films (74\% 1B, 95\% 3B, 89\% 3A). OLEDs with different architectures containing them showed modest EQEs (in the range of $0.5 \%$ ) which has been attributed to charge carrier injection and balance issues, and the development of new matrices with HOMOs and LUMOs more adequate for these compounds or more effective interface engineering would be necessary.

White light with satisfactory photometric and colorimetric parameters was obtained by combination of $\mathbf{1 B}$ or $\mathbf{3 B}$ as blue with $[\mathrm{Pt}(\mathrm{bzq})(\mathrm{CN})(\mathrm{CNXyl})](\mathbf{R})$ as red emitters in two-component remote phosphor devices. Using $\mathbf{1 B}$ or $\mathbf{3 B}$ and changing the blue: red ratio under a $365 \mathrm{~nm}$ LED pumping source, warm white light with optimal CRI and $D_{\mathrm{uv}}$ values and a great range of nominal CCT values $(4000 \mathrm{~K}, 3500 \mathrm{~K}, 3000 \mathrm{~K}, 2500 \mathrm{~K}$ and $2000 \mathrm{~K}$ ) could be obtained. The emission spectra of these systems mimic that of the incandescent light, with a much reduced impact of the blue component. These findings show a great promise of these systems for photo-biologically healthier solid-state lighting.

\section{Experimental}

\section{General information is included in the ESI. $\dagger$}

Synthesis and characterization of $\left[\operatorname{Pt}\left(\operatorname{Naph}^{\wedge} \mathbf{C}^{*}\right)(\mathbf{d p p m})\right] \mathbf{P F}_{6}$ (1A). dppm (87.0 mg, $0.22 \mathrm{mmol}$ ) and $\mathrm{KPF}_{6}(41.2 \mathrm{mg}, 0.22 \mathrm{mmol})$ were added to a suspension of $\mathbf{A}(96.1 \mathrm{mg}, 0.11 \mathrm{mmol})$ in acetone $(30 \mathrm{~mL})$ at room temperature. After $1 \mathrm{~h}$ of reaction, the solvent was removed under reduced pressure and the residue was treated with dichloromethane $(40 \mathrm{~mL})$. The solution was filtered through Celite and the solvent was removed under reduced pressure. The residue was treated with diethyl ether, filtered, and washed with diethyl ether to give $\mathbf{1 A}$ as a yellow solid. Yield: $147.5 \mathrm{mg}, 72 \%$. Anal. calcd for $\mathrm{C}_{39} \mathrm{H}_{33} \mathrm{~F}_{6} \mathrm{~N}_{2} \mathrm{P}_{3} \mathrm{Pt} \mathrm{CH}_{2} \mathrm{Cl}_{2}$ : $\mathrm{C} 47.26$, $\mathrm{H}$ 3.47, $\mathrm{N}$ 2.75; found: $\mathrm{C} 47.64, \mathrm{H} 3.49, \mathrm{~N} 3.04 .{ }^{1} \mathrm{H}$ NMR (400 MHz, $\mathrm{CD}_{2} \mathrm{Cl}_{2}$ ): $\delta=7.87-7.71$ (m, 9H, $\mathrm{Ho}$ and $\mathrm{H}_{12}$ ), 7.66$7.63\left(\mathrm{~m}, 1 \mathrm{H}, \mathrm{H}_{2}\right), 7.63-7.46\left(\mathrm{~m}, 14 \mathrm{H}, \mathrm{H} m, \mathrm{H} p, \mathrm{H}_{14}\right.$ and $\left.\mathrm{H}_{7}\right), 7.37$ $\left(\mathrm{ddd},{ }^{3} J_{\mathrm{H} 11,12}=8.2,{ }^{3} J_{\mathrm{H} 11,10}=6.9,{ }^{4} J_{\mathrm{H} 11,9}=1.2,1 \mathrm{H}, \mathrm{H}_{11}\right), 7.26$ (ddd, $\left.{ }^{3} J_{\mathrm{H} 10,9}=8.1,{ }^{3} J_{\mathrm{H} 10,11}=6.9,{ }^{4} J_{\mathrm{H} 10,12}=1.1,1 \mathrm{H}, \mathrm{H}_{10}\right), 7.17\left(\mathrm{~d},{ }^{3} J_{\mathrm{H} 9,10}=\right.$ 8.1, $\left.1 \mathrm{H}, \mathrm{H}_{9}\right), 7.12\left(\mathrm{~m}, 1 \mathrm{H}, \mathrm{H}_{3}\right), 4.90-4.71\left(\mathrm{~m}, 2 \mathrm{H}, \mathrm{CH}_{2}\right.$ (dppm)), $3.26\left(\mathrm{~s}, 3 \mathrm{H}, \mathrm{H}_{4}\right) .{ }^{13} \mathrm{C}\left\{{ }^{1} \mathrm{H}\right\}$ NMR plus HMBC and HSQC (101 MHz, $\left.\mathrm{CD}_{2} \mathrm{Cl}_{2}\right): \delta=173.0\left(\mathrm{C}_{1}\right), 146.8\left(\mathrm{~s}, \mathrm{C}_{5}\right), 141.6\left(\mathrm{C}_{6}\right), 139.8\left(\mathrm{dd},{ }^{3} J_{\mathrm{C}, \mathrm{P}}=\right.$ 11.2, $\left.{ }^{3} J_{\mathrm{C}, \mathrm{P}}=3.8, \mathrm{C}_{7}\right), 134.2\left(\mathrm{~d},{ }^{2} J_{\mathrm{C}, \mathrm{P}}=12.5,4 \mathrm{C}, \mathrm{Co}\right), 133.9\left(\mathrm{~d},{ }^{2} J_{\mathrm{C}, \mathrm{P}}=\right.$ 12.8, 4C, Co), 133.2 (s, 2C, Cp), 133.1 (s, 2C, Cp), 132.8 (s, C ${ }_{13}$ ), $130.4\left(\mathrm{~d},{ }^{3} J_{\mathrm{C}, \mathrm{P}}=10.8,4 \mathrm{C}, \mathrm{Cm}\right), 130.1\left(\mathrm{~d},{ }^{3} J_{\mathrm{C}, \mathrm{P}}=11.3,4 \mathrm{C}, \mathrm{Cm}\right), 128.1$ and $128.0\left(\mathrm{~s}, 2 \mathrm{C}, \mathrm{C}_{9}\right.$ and $\left.\mathrm{C}_{12}\right), 126.9\left(\mathrm{~s}, \mathrm{C}_{11}\right), 126.6\left(\mathrm{~d},{ }^{1} J_{\mathrm{C}, \mathrm{P}}=8.1\right.$, $2 \mathrm{C}, \mathrm{C} i), 126.2\left(\mathrm{~s}, \mathrm{C}_{10}\right), 126.1\left(\mathrm{~d},{ }^{1} J_{\mathrm{C}, \mathrm{P}}=7.9,2 \mathrm{C}, \mathrm{C} i\right), 124.4\left(\mathrm{~d},{ }^{4} J_{\mathrm{C}, \mathrm{P}}=\right.$ $\left.4.5, \mathrm{C}_{3}\right), 116.4\left(\mathrm{~d},{ }^{4} J_{\mathrm{C}, \mathrm{P}}=2.3, \mathrm{C}_{2}\right), 109.1\left(\mathrm{~d},{ }^{4} J_{\mathrm{C}, \mathrm{P}}=2.9,{ }^{3} J_{\mathrm{C}, \mathrm{Pt}}=19.5\right.$, $\left.\mathrm{C}_{14}\right), 50.1\left(\mathrm{dd},{ }^{1} J_{\mathrm{C}, \mathrm{P}}=31.0,{ }^{1} J_{\mathrm{C}, \mathrm{P}}=28.5, \mathrm{CH}_{2}(\mathrm{dppm})\right), 39.0(\mathrm{dd}$, $\left.{ }^{4} J_{\mathrm{C}, \mathrm{P}}=4.2,{ }^{4} J_{\mathrm{C}, \mathrm{P}}=1.7, \mathrm{C}_{4}\right) . \mathrm{C}_{8}$ overlapped with Co as detected by HMBC. MS (MALDI+): $m / z(100) 786.1[\mathrm{M}]^{+} . \Lambda_{\mathrm{M}}\left(5 \times 10^{-4} \mathrm{M}\right.$ acetone solution): $65.1 \Omega^{-1} \mathrm{~cm}^{2} \mathrm{~mol}^{-1}$.

Synthesis and characterization of $\left[\mathrm{Pt}\left(\mathrm{Naph}^{\wedge} \mathbf{C}^{*}\right)(\mathrm{dppe})\right] \mathbf{P F}_{6}$ (2A). It was prepared following the method described for $\mathbf{1 A}$ with dppe (127.0 mg, $0.32 \mathrm{mmol}$ ), $\mathrm{KPF}_{6}(59.9 \mathrm{mg}, 0.32 \mathrm{mmol}$ ) and $\mathbf{A}$ (139.6 mg, $0.16 \mathrm{mmol}$ ) (2 h). $2 \mathrm{~A}$ was obtained as a pale yellow solid (yield: $259.4 \mathrm{mg}, 86 \%$ ). Anal. calcd for $\mathrm{C}_{40} \mathrm{H}_{35} \mathrm{~F}_{6} \mathrm{~N}_{2} \mathrm{P}_{3}$ Pt: $\mathrm{C}$ 50.80, $\mathrm{H}$ 3.73, N 2.96; found: $\mathrm{C} 50.75, \mathrm{H}$ 3.59, N 3.20. ${ }^{1} \mathrm{H}$ NMR (400 MHz, $\left.\mathrm{CD}_{2} \mathrm{Cl}_{2}\right): \delta=8.00-7.90(\mathrm{~m}, 8 \mathrm{H}$, $\mathrm{Ho}$ ) , 7.75-7.70 (m, 2H, $\mathrm{H}_{12}$ and $\mathrm{H}_{2}$ ), 7.68-7.49 (m, 14H, $\mathrm{H} m, \mathrm{H} p$, $\mathrm{H}_{14}$ and $\left.\mathrm{H}_{7}\right), 7.34\left(\mathrm{ddd},{ }^{3} J_{\mathrm{H} 11,12}=8.1,{ }^{3} J_{\mathrm{H} 11,10}=7.0,{ }^{4} J_{\mathrm{H} 11,9}=1.1\right.$, $\left.1 \mathrm{H}, \mathrm{H}_{11}\right), 7.20\left(\mathrm{ddd},{ }^{3} J_{\mathrm{H} 10,9}=8.2,{ }^{3} J_{\mathrm{H} 10,11}=7.0,{ }^{4} J_{\mathrm{H} 10,12}=1.1,1 \mathrm{H}\right.$, $\left.\mathrm{H}_{10}\right), 7.08-7.04\left(\mathrm{~m}, 1 \mathrm{H}, \mathrm{H}_{3}\right), 7.03\left(\mathrm{~d},{ }^{3} J_{\mathrm{H} 9,10}=8.2,1 \mathrm{H}, \mathrm{H}_{9}\right)$, 3.06 (s, 3H, $\mathrm{H}_{4}$ ), 2.39 (m, 4H, (dppe)). ${ }^{13} \mathrm{C}\left\{{ }^{1} \mathrm{H}\right\}$ NMR plus HMBC and HSQC (101 MHz, $\left.\mathrm{CD}_{2} \mathrm{Cl}_{2}\right): \delta=173.3$ (dd, ${ }^{2} J_{\mathrm{C} 1-\mathrm{P} \text { trans }}=129.0$; $\left.{ }^{2} J_{\mathrm{C} 1-\mathrm{P} \text { cis }}=7.6, \mathrm{C}_{1}\right), 146.7\left(\mathrm{~s}, \mathrm{C}_{5}\right), 142.8\left(\mathrm{dd},{ }^{2} J_{\mathrm{C}, \mathrm{P} \text { cis }}=5.8,{ }^{2} J_{\mathrm{C}, \mathrm{P} \text { trans }}=\right.$ 104.1, $\left.\mathrm{C}_{6}\right), 140.7\left(\mathrm{dd},{ }^{3} J_{\mathrm{C}, \mathrm{P}}=10.1,{ }^{3} J_{\mathrm{C}, \mathrm{P}}=2.0,{ }^{2} J_{\mathrm{C}, \mathrm{Pt}}=52.5, \mathrm{C}_{7}\right)$, $134.8\left(\mathrm{~d},{ }^{2} J_{\mathrm{C}, \mathrm{P}}=11.9,{ }^{3} J_{\mathrm{C}, \mathrm{Pt}}=25.3,4 \mathrm{C}, \mathrm{Co}\right), 134.2\left(\mathrm{~d},{ }^{2} J_{\mathrm{C}, \mathrm{P}}=12.7\right.$, $\left.{ }^{3} J_{\mathrm{C}, \mathrm{Pt}}=19.8,4 \mathrm{C}, \mathrm{Co}\right), 133.6\left(\mathrm{dd},{ }^{4} J_{\mathrm{C}, \mathrm{P}}=7.4,{ }^{4} J_{\mathrm{C}, \mathrm{P}}=3.0, \mathrm{C}_{8}\right), 133.2$ $\left(\mathrm{d},{ }^{4} J_{\mathrm{C}, \mathrm{P}}=2.4,2 \mathrm{C}, \mathrm{C} p\right), 133.0\left(\mathrm{~d},{ }^{4} J_{\mathrm{C}, \mathrm{P}}=2.5,2 \mathrm{C}, \mathrm{C} p\right), 132.4\left(\mathrm{~s}, \mathrm{C}_{13}\right)$, $130.4\left(\mathrm{~d},{ }^{3} J_{\mathrm{C}, \mathrm{P}}=10.7,4 \mathrm{C}, \mathrm{Cm}\right), 130.0\left(\mathrm{~d},{ }^{3} J_{\mathrm{C}, \mathrm{P}}=11.1,4 \mathrm{C}, \mathrm{Cm}\right)$, $129.3\left(\mathrm{~d},{ }^{1} J_{\mathrm{C}, \mathrm{P}}=46.7,2 \mathrm{C}, \mathrm{C} i\right), 127.9$ and 127.8 (s, 2C, $\mathrm{C}_{9}$ and $\mathrm{C}_{12}$ ), $127.3\left(\mathrm{~d},{ }^{1} J_{\mathrm{C}, \mathrm{P}}=54.7,2 \mathrm{C}, \mathrm{Ci}\right), 126.8\left(\mathrm{~s}, \mathrm{C}_{11}\right), 126.0\left(\mathrm{~s}, \mathrm{C}_{10}\right), 125.3$ $\left(\mathrm{d},{ }^{4} J_{\mathrm{C}, \mathrm{P}}=4.5,{ }^{3} J_{\mathrm{C}-\mathrm{Pt}}=29.6, \mathrm{C}_{3}\right), 116.4\left(\mathrm{~d},{ }^{4} J_{\mathrm{C}, \mathrm{P}}=2.3,{ }^{3} J_{\mathrm{C}, \mathrm{Pt}}=35.8\right.$, $\left.\mathrm{C}_{2}\right), 108.8\left(\mathrm{~d},{ }^{4} J_{\mathrm{C}, \mathrm{P}}=3.1,{ }^{3} J_{\mathrm{C}, \mathrm{Pt}}=23.0, \mathrm{C}_{14}\right), 39.5\left(\mathrm{~d},{ }^{4} J_{\mathrm{C}, \mathrm{P}}=2.9 \mathrm{C}_{4}\right)$, $32.4\left(\mathrm{dd},{ }^{1} J_{\mathrm{C}, \mathrm{P}}=37.0,{ }^{2} J_{\mathrm{C}, \mathrm{P}}=10.7, \mathrm{CH}_{2}(\mathrm{dppe})\right), 31.4\left(\mathrm{dd},{ }^{1} J_{\mathrm{C}, \mathrm{P}}=\right.$ $39.3,{ }^{2} J_{\mathrm{C}, \mathrm{P}}=12.8, \mathrm{CH}_{2}$ (dppe)). IR (ATR): $\nu=831,556\left(\mathrm{~s}, \mathrm{PF}_{6}\right) . \mathrm{MS}$ (MALDI +$): m / z(100) 800.2[\mathrm{M}]^{+} . \Lambda_{\mathrm{M}}\left(5 \times 10^{-4} \mathrm{M}\right.$ acetone solution): $62.9 \Omega^{-1} \mathrm{~cm}^{2} \mathrm{~mol}^{-1}$.

Synthesis and characterization of $\left[\operatorname{Pt}\left(\operatorname{Naph}^{\wedge} C^{*}\right)(\mathbf{d p p b z})\right] \mathbf{P F}_{6}$ (3A). It was prepared following the method described for $\mathbf{1 A}$ with dppbz (126.2 mg, $0.27 \mathrm{mmol}$ ), $\mathrm{KPF}_{6}(51.5 \mathrm{mg}, 0.27 \mathrm{mmol})$ and $\mathbf{A}$ (120.0 mg, $0.14 \mathrm{mmol}$ ) (3 h). 3A was obtained as a pale yellow solid (yield: $207.4 \mathrm{mg}, 76 \%$ ). Anal. calcd for $\mathrm{C}_{44} \mathrm{H}_{35} \mathrm{~F}_{6} \mathrm{~N}_{2} \mathrm{P}_{3} \mathrm{Pt}$ : 
C 53.18, H 3.55, N 2.84; found: C 52.91, H 3.40, N 2.84. ${ }^{1} \mathrm{H}$ NMR (400 MHz, $\left.\mathrm{CD}_{2} \mathrm{Cl}_{2}\right): \delta=7.86-7.77(\mathrm{~m}, 4 \mathrm{H}, \mathrm{Ho}), 7.76-7.72(\mathrm{~m}, 1 \mathrm{H}$, $\mathrm{H}_{12}$ ), 7.72-7.69 (m, 1H, $\left.\mathrm{H}_{2}\right)$, 7.69-7.39 (m, 22H, $\mathrm{H}_{\mathrm{a}}, \mathrm{H}_{\mathrm{b}}, \mathrm{H}_{\mathrm{c}}, \mathrm{H}_{\mathrm{d}}, \mathrm{Ho}$, $\mathrm{H} m, \mathrm{H} p, \mathrm{H}_{14}$ and $\left.\mathrm{H}_{7}\right), 7.37\left(\mathrm{ddd},{ }^{3} J_{\mathrm{H} 11,12}=8.1,{ }^{3} J_{\mathrm{H} 11,10}=7.1,{ }^{4} J_{\mathrm{H} 11,9}=\right.$ $\left.1.2,1 \mathrm{H}, \mathrm{H}_{11}\right), 7.25\left(\mathrm{ddd},{ }^{3} J_{\mathrm{H} 10,9}=8.1,{ }^{3} J_{\mathrm{H} 10,11}=7.1,{ }^{4} J_{\mathrm{H} 10,12}=1.1,1 \mathrm{H}\right.$, $\left.\mathrm{H}_{10}\right), 7.05-6.99\left(\mathrm{~m}, 1 \mathrm{H}, \mathrm{H}_{3}\right), 6.97\left(\mathrm{~d},{ }^{3} \mathrm{~J}_{\mathrm{H} 9,10}=8.1,1 \mathrm{H}, \mathrm{H}_{9}\right), 3.05$ (s, 3H, H $\left.{ }_{4}\right) \cdot{ }^{13} \mathrm{C}\left\{{ }^{1} \mathrm{H}\right\}$ NMR plus HMBC and HSQC (101 MHz, $\left.\mathrm{CD}_{2} \mathrm{Cl}_{2}\right): \delta=172.3\left(\mathrm{C}_{1}\right), 146.6\left(\mathrm{~s}, \mathrm{C}_{5}\right), 142.6\left(\mathrm{dd},{ }^{2} J_{\mathrm{C}, \mathrm{P} c i s}=5.9\right.$, $\left.{ }^{2} J_{\mathrm{C}, \mathrm{P} \text { trans }}=98.7, \mathrm{C}_{6}\right), 140.5\left(\mathrm{dd},{ }^{3} J_{\mathrm{C}, \mathrm{P}}=9.3,{ }^{3} J_{\mathrm{C}, \mathrm{P}}=2.4, \mathrm{C}_{7}\right), 143.8-$ $134.3(\mathrm{~m}, 8 \mathrm{C}, \mathrm{Co}), 134.2-133.1\left(\mathrm{~m}, 5 \mathrm{C}, \mathrm{C}_{\mathrm{a}}, \mathrm{C}_{\mathrm{b}}, \mathrm{C}_{\mathrm{c}}, \mathrm{C}_{\mathrm{d}}\right.$ and $\left.\mathrm{C}_{8}\right), 132.8$ $\left(\mathrm{d},{ }^{4} J_{\mathrm{C}, \mathrm{P}}=2.3,2 \mathrm{C}, \mathrm{C} p\right), 132.6\left(\mathrm{~d},{ }^{4} J_{\mathrm{C}, \mathrm{P}}=2.5,2 \mathrm{C}, \mathrm{C} p\right), 132.4\left(\mathrm{~s}, \mathrm{C}_{13}\right)$, $130.2\left(\mathrm{~d},{ }^{3} J_{\mathrm{C}, \mathrm{P}}=11.0,4 \mathrm{C}, \mathrm{Cm}\right), 129.8\left(\mathrm{~d},{ }^{3} J_{\mathrm{C}, \mathrm{P}}=11.4,4 \mathrm{C}, \mathrm{Cm}\right)$, $129.5\left(\mathrm{~d},{ }^{1} J_{\mathrm{C}, \mathrm{P}}=1.3,2 \mathrm{C}, \mathrm{C} i\right), 128.4\left(\mathrm{~d},{ }^{1} J_{\mathrm{C}, \mathrm{P}}=1.3,2 \mathrm{C}, \mathrm{C} i\right), 128.1\left(\mathrm{~s}, \mathrm{C}_{9}\right)$, $127.8\left(\mathrm{~s}, \mathrm{C}_{12}\right), 126.9\left(\mathrm{~s}, \mathrm{C}_{11}\right), 126.1\left(\mathrm{~s}, \mathrm{C}_{10}\right), 125.3\left(\mathrm{~d},{ }^{4} J_{\mathrm{C}, \mathrm{P}}=4.4, \mathrm{C}_{3}\right)$, $116.6\left(\mathrm{~d},{ }^{4} J_{\mathrm{C}, \mathrm{P}}=2.3,{ }^{3} J_{\mathrm{C}, \mathrm{Pt}}=22.8, \mathrm{C}_{2}\right), 108.8\left(\mathrm{~d},{ }^{4} J_{\mathrm{C}, \mathrm{P}}=3.0,{ }^{3} J_{\mathrm{C}, \mathrm{Pt}}=\right.$ 23.0, $\mathrm{C}_{14}$ ), 39.4 (s, br, $\mathrm{C}_{4}$ ). IR (ATR): $\nu=830,545$ (s, PF I $_{6}$. MS (MALDI+): $m / z(100) 848.2[\mathrm{M}]^{+} . \Lambda_{\mathrm{M}}\left(5 \times 10^{-4} \mathrm{M}\right.$ acetone solution): $66.0 \Omega^{-1} \mathrm{~cm}^{2} \mathrm{~mol}^{-1}$.

Synthesis and characterization of $\left[\operatorname{Pt}\left(\operatorname{EtO}_{2} C_{-} C^{\wedge} C^{*}\right)(\mathbf{d p p m})\right] \mathbf{P F}_{6}$ (1B). It was prepared following the method described for $\mathbf{1 A}$ with dppm (104.1 mg, $0.26 \mathrm{mmol}$ ), $\mathrm{KPF}_{6}$ (104.1 mg, $0.26 \mathrm{mmol}$ ) and $\mathbf{B}$ (119.8 $\mathrm{mg}, 0.13 \mathrm{mmol}$ ) ( $2 \mathrm{~h}$ ). $2 \mathrm{~B}$ was obtained as a pale yellow solid (yield: $204.8 \mathrm{mg}, 83 \%$ ). Anal. calcd for $\mathrm{C}_{38} \mathrm{H}_{35} \mathrm{~F}_{6} \mathrm{~N}_{2} \mathrm{O}_{2} \mathrm{P}_{3} \mathrm{Pt}$ : C 47.86, H 3.70, N 2.94; found: C 47.56, H 3.59, N 2.87. ${ }^{1} \mathrm{H}$ NMR $\left(400 \mathrm{MHz}, \mathrm{CD}_{2} \mathrm{Cl}_{2}\right): \delta=7.92-7.80\left(\mathrm{~m}, 2 \mathrm{H}, \mathrm{H}_{7}\right.$ and $\left.\mathrm{H}_{10}\right), 7.80-7.67$ $(\mathrm{m}, 8 \mathrm{H}, \mathrm{Ho}), 7.64-7.44\left(\mathrm{~m}, 13 \mathrm{H}, \mathrm{Hm}, \mathrm{H} p\right.$ and $\mathrm{H}_{2}$ ), 7.26 (dd, $\left.{ }^{3} J_{\mathrm{H} 9,10}=8.4,{ }^{4} J_{\mathrm{H} 9,7}=1.9, \mathrm{H}_{9}\right), 7.08\left(\mathrm{~m}, 1 \mathrm{H}, \mathrm{H}_{3}\right), 4.79\left(\mathrm{~m}, 2 \mathrm{H}, \mathrm{CH}_{2}\right.$ $(\mathrm{dppm})), 4.08\left(\mathrm{q},{ }^{3} \mathrm{~J}_{\mathrm{H}, \mathrm{H}}=7.1,2 \mathrm{H}, \mathrm{CH}_{2}(\mathrm{OEt})\right), 3.25\left(\mathrm{~s}, 3 \mathrm{H}, \mathrm{H}_{4}\right), 1.10$ $\left(\mathrm{t}, 3 \mathrm{H},{ }^{3} J_{\mathrm{H}, \mathrm{H}}=7.1, \mathrm{CH}_{3}(\mathrm{OEt})\right) .{ }^{13} \mathrm{C}\left\{{ }^{1} \mathrm{H}\right\} \mathrm{NMR}$ plus $\mathrm{HMBC}$ and HSQC (101 MHz, $\mathrm{CD}_{2} \mathrm{Cl}_{2}$ ): $\delta=172.8\left(\mathrm{C}_{1}\right), 166.2$ (s, COO), 152.1 $\left(\mathrm{s}, \mathrm{C}_{5}\right), 142.6\left(\mathrm{~d},{ }^{2} J_{\mathrm{P}, \mathrm{C}}=19.9, \mathrm{C}_{6}\right), 140.7\left(\mathrm{dd},{ }^{3} J_{\mathrm{C}, \mathrm{P}}=10.5,{ }^{3} J_{\mathrm{C}, \mathrm{P}}=\right.$ $\left.5.0,{ }^{2} J_{\mathrm{C}, \mathrm{Pt}}=47.2, \mathrm{C}_{7}\right), 134.0\left(\mathrm{~d},{ }^{2} J_{\mathrm{C}, \mathrm{P}}=11.8,{ }^{3} J_{\mathrm{C}, \mathrm{Pt}}=24.2,4 \mathrm{C}, \mathrm{Co}\right)$, $133.9\left(\mathrm{~d},{ }^{2} J_{\mathrm{C}, \mathrm{P}}=11.9,{ }^{3} J_{\mathrm{C}, \mathrm{Pt}}=19.7,4 \mathrm{C}, \mathrm{Co}\right), 133.3(\mathrm{~s}, 2 \mathrm{C}, \mathrm{C} p), 133.2$ $(\mathrm{s}, 2 \mathrm{C}, \mathrm{C} p), 130.4\left(\mathrm{~d},{ }^{3} J_{\mathrm{C}, \mathrm{P}}=10.4,4 \mathrm{C}, \mathrm{Cm}\right), 130.2\left(\mathrm{~d},{ }^{3} J_{\mathrm{C}, \mathrm{P}}=10.4\right.$, $4 \mathrm{C}, \mathrm{Cm}), 129.5\left(\mathrm{~s}, \mathrm{C}_{10}\right), 127.9\left(\mathrm{dd},{ }^{1} J_{\mathrm{P}, \mathrm{C}}=37.9,{ }^{3} J_{\mathrm{P}, \mathrm{C}}=10.6,2 \mathrm{C}, \mathrm{C} i\right)$, $126.1\left(\mathrm{dd},{ }^{1} J_{\mathrm{P}, \mathrm{C}}=44.8,{ }^{3} J_{\mathrm{P}, \mathrm{C}}=12.2,2 \mathrm{C}, \mathrm{Ci}\right), 124.2\left(\mathrm{~d},{ }^{4} J_{\mathrm{C}, \mathrm{P}}=3.6, \mathrm{C}_{3}\right)$, $116.7\left(\mathrm{~s}, \mathrm{C}_{2}\right), 111.8\left(\mathrm{~s},{ }^{4} J_{\mathrm{C}, \mathrm{Pt}}=25.1, \mathrm{C}_{9}\right), 61.1\left(\mathrm{~s}, \mathrm{CH}_{2}(\mathrm{OEt})\right), 50.0$ $\left(\mathrm{t},{ }^{1} J_{\mathrm{C}, \mathrm{P}}=30.6, \mathrm{CH}_{2}(\mathrm{dppm})\right), 39.0\left(\mathrm{~s}, \mathrm{C}_{4}\right), 14.5\left(\mathrm{~s}, \mathrm{CH}_{3}(\mathrm{OEt})\right)$. $\mathrm{C}_{8}$ undetected. IR (ATR): $\nu=1696(\mathrm{~m}, \mathrm{C}=\mathrm{O}), 836,556\left(\mathrm{~s}, \mathrm{PF}_{6}\right)$. MS (MALDI+): $m / z(100) 808.1[\mathrm{M}]^{+} . \Lambda_{\mathrm{M}}\left(5 \times 10^{-4} \mathrm{M}\right.$ acetone solution): $68.4 \Omega^{-1} \mathrm{~cm}^{2} \mathrm{~mol}^{-1}$.

Synthesis and characterization of $\left[\operatorname{Pt}\left(\right.\right.$ EtO $\left.\left._{2} C_{-}-C^{\wedge} C^{*}\right)\left(\mathbf{d p p e}^{2}\right)\right] \mathbf{P F}_{6}$ (2B). It was prepared following the method described for $\mathbf{1 A}$ with dppe (110.2 mg, $0.27 \mathrm{mmol}$ ), $\mathrm{KPF}_{6}(51.3 \mathrm{mg}, 0.27 \mathrm{mmol})$ and $\mathbf{B}$ (124.0 mg, $0.13 \mathrm{mmol}$ ) ( $2 \mathrm{~h}$ ). $2 \mathrm{~B}$ was obtained as a pale yellow solid (yield: $173.2 \mathrm{mg}, 66 \%$ ). Anal. calcd for $\mathrm{C}_{39} \mathrm{H}_{37} \mathrm{~F}_{6} \mathrm{~N}_{2} \mathrm{O}_{2} \mathrm{P}_{3} \mathrm{Pt}$ : C 48.40, H 3.85, N 2.89; found: C 48.57, H 3.96, N 2.80. ${ }^{1} \mathrm{H}$ NMR (400 MHz, $\mathrm{CD}_{2} \mathrm{Cl}_{2}$ ): $\delta=7.90-8.00\left(\mathrm{~m}, 5 \mathrm{H}, \mathrm{Ho}\right.$ and $\mathrm{H}_{7}$ ), 7.90-7.81 $(\mathrm{m}, 4 \mathrm{H}, \mathrm{Ho}), 7.79\left(\mathrm{dd},{ }^{3} J_{\mathrm{H} 9,10}=8.2,{ }^{4} J_{\mathrm{H} 9,7}=1.6, \mathrm{H}_{9}\right), 7.69-7.49(\mathrm{~m}$, $13 \mathrm{H}, \mathrm{H} m, \mathrm{H} p$ and $\left.\mathrm{H}_{2}\right), 7.26\left(\mathrm{dd},{ }^{5} J_{10,7}=2.3,{ }^{3} J_{9,10}=8.2,{ }^{4} J_{10, \mathrm{Pt}}=\right.$ 10.0, 1H, $\left.\mathrm{H}_{10}\right), 7.00\left(\mathrm{~m}, 1 \mathrm{H}, \mathrm{H}_{3}\right), 4.06\left(\mathrm{q},{ }^{3} \mathrm{~J}_{\mathrm{H}, \mathrm{H}}=7.1,2 \mathrm{H}, \mathrm{CH}_{2}\right.$ (OEt)), $3.05\left(\mathrm{~s}, 3 \mathrm{H}, \mathrm{H}_{4}\right), 2.36(\mathrm{~m}, 4 \mathrm{H},(\mathrm{dppe})), 1.10\left(\mathrm{t}, 3 \mathrm{H},{ }^{3} J_{\mathrm{H}, \mathrm{H}}=\right.$ 7.1, $\left.\mathrm{CH}_{3}(\mathrm{OEt})\right) .{ }^{13} \mathrm{C}\left\{{ }^{1} \mathrm{H}\right\}$ NMR plus HMBC and HSQC (101 MHz, $\left.\mathrm{CD}_{2} \mathrm{Cl}_{2}\right): \delta=173.4\left(\mathrm{C}_{1}\right), 166.2(\mathrm{~s}, \mathrm{COO}), 151.8\left(\mathrm{~s}, \mathrm{C}_{5}\right), 144.0\left(\mathrm{~s}, \mathrm{C}_{6}\right)$, $141.8\left(\mathrm{~d},{ }^{3} J_{\mathrm{C}, \mathrm{P}}=10.7, \mathrm{C}_{7}\right), 134.7\left(\mathrm{~d},{ }^{2} J_{\mathrm{C}, \mathrm{P}}=11.9,{ }^{3} J_{\mathrm{C}, \mathrm{Pt}}=25.0,4 \mathrm{C}, \mathrm{Co}\right)$, $134.2\left(\mathrm{~d},{ }^{2} J_{\mathrm{C}, \mathrm{P}}=12.5,{ }^{3} J_{\mathrm{C}, \mathrm{Pt}}=21.0,4 \mathrm{C}, \mathrm{Co}\right), 133.3(\mathrm{~s}, 2 \mathrm{C}, \mathrm{C} p), 133.0$ $(\mathrm{s}, 2 \mathrm{C}, \mathrm{C} p), 130.5\left(\mathrm{~d},{ }^{3} J_{\mathrm{C}, \mathrm{P}}=10.7,4 \mathrm{C}, \mathrm{Cm}\right), 130.0\left(\mathrm{~d},{ }^{3} J_{\mathrm{C}, \mathrm{P}}=\right.$ 11.1, 4C, Cm), 129.1 (s, C 9 ), 128.9 (d, $\left.{ }^{1} J_{\mathrm{P}, \mathrm{C}}=47.2,2 \mathrm{C}, \mathrm{C} i\right), 127.0$ $\left(\mathrm{d},{ }^{1} J_{\mathrm{P}, \mathrm{C}}=55.0,2 \mathrm{C}, \mathrm{Ci}\right), 125.0\left(\mathrm{~s}, \mathrm{br}, \mathrm{C}_{3}\right), 116.8\left(\mathrm{~s}, \mathrm{C}_{2}\right), 111.8(\mathrm{~s}, \mathrm{br}$, $\mathrm{C}_{10}$ ), 61.0 (s, $\mathrm{CH}_{2}$ (OEt)), 39.5 (s, $\mathrm{C}_{4}$ ), 32.1 (m, 2C (dppe)), 14.5 (s, $\mathrm{CH}_{3}$ (OEt)). $\mathrm{C}_{8}$ undetected. IR (ATR): $\nu=1705(\mathrm{~m}, \mathrm{C}=\mathrm{O}), 831$, $556\left(\mathrm{~s}, \mathrm{PF}_{6}\right)$. MS (MALDI+): $m / z(100) 822.2[\mathrm{M}]^{+} . \Lambda_{\mathrm{M}}\left(5 \times 10^{-4} \mathrm{M}\right.$ acetone solution): $64.8 \Omega^{-1} \mathrm{~cm}^{2} \mathrm{~mol}^{-1}$.

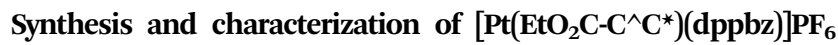
(3B). It was prepared following the method described for $\mathbf{1 A}$ with dppbz (120.2 mg, $0.26 \mathrm{mmol}$ ), $\mathrm{KPF}_{6}(50.0 \mathrm{mg}, 0.27 \mathrm{mmol})$ and $\mathbf{B}$ (120.4 mg, $0.13 \mathrm{mmol}$ ) ( $2 \mathrm{~h}$ ). $3 \mathbf{B}$ was obtained as a pale yellow solid (yield: $205.2 \mathrm{mg}, 77 \%$ ). Anal. calcd for $\mathrm{C}_{43} \mathrm{H}_{37} \mathrm{~F}_{6} \mathrm{~N}_{2} \mathrm{O}_{2} \mathrm{P}_{3} \mathrm{Pt}$ : C 50.85, $\mathrm{H}$ 3.67, N 2.76; found: C 50.79, H 3.63, N 2.82. ${ }^{1} \mathrm{H}$ NMR $(400 \mathrm{MHz}$, $\left.\mathrm{CD}_{2} \mathrm{Cl}_{2}\right): \delta=8.14\left(\mathrm{dm},{ }^{4} J_{\mathrm{H}, \mathrm{P}}=7.0,{ }^{3} J_{\mathrm{H}, \mathrm{Pt}}=52.1,1 \mathrm{H}, \mathrm{H}_{7}\right), 7.90-7.79(\mathrm{~m}$, $5 \mathrm{H}, \mathrm{Ho}$ and $\left.\mathrm{H}_{9}\right)$, 7.74-7.66 (m, 4H, $\left.\mathrm{Ho}\right), 7.64-7.38\left(\mathrm{~m}, 17 \mathrm{H}, \mathrm{H}_{\mathrm{a}}, \mathrm{H}_{\mathrm{b}}\right.$, $\mathrm{H}_{\mathrm{c}}, \mathrm{H}_{\mathrm{d}}, \mathrm{H} m, \mathrm{H} p$ and $\left.\mathrm{H}_{2}\right), 7.29\left(\mathrm{dd},{ }^{5} J_{\mathrm{H} 10,7}=2.3,{ }^{3} J_{\mathrm{H} 10,9}=8.2,{ }^{4} J_{\mathrm{H} 10, \mathrm{Pt}}=\right.$ 10.2, 1H, $\left.\mathrm{H}_{10}\right), 7.02\left(\mathrm{~m}, 1 \mathrm{H}, \mathrm{H}_{3}\right), 4.14\left(\mathrm{q},{ }^{3} \mathrm{~J}_{\mathrm{H}, \mathrm{H}}=7.1,2 \mathrm{H}, \mathrm{CH}_{2}(\mathrm{OEt})\right.$ ), $3.07\left(\mathrm{~s}, 3 \mathrm{H}, \mathrm{H}_{4}\right), 1.22\left(\mathrm{t}, 3 \mathrm{H},{ }^{3} J_{\mathrm{H}, \mathrm{H}}=7.1, \mathrm{CH}_{3}(\mathrm{OEt})\right) .{ }^{13} \mathrm{C}\left\{{ }^{1} \mathrm{H}\right\} \mathrm{NMR}$ plus $\mathrm{HMBC}$ and HSQC (101 MHz, $\left.\mathrm{CD}_{2} \mathrm{Cl}_{2}\right): \delta=172.2\left(\mathrm{dd},{ }^{2} J_{\mathrm{C}, \text { Ptrans }}=\right.$ 129.9, $\left.{ }^{2} J_{\mathrm{C}, \mathrm{P} c i s}=7.52, \mathrm{C}_{1}\right), 166.2(\mathrm{~s}, \mathrm{COO}), 151.7\left(\mathrm{~s}, \mathrm{C}_{5}\right), 141.1(\mathrm{dd}$, $\left.{ }^{3} J_{\mathrm{C}, \mathrm{P}}=9.7,{ }^{3} J_{\mathrm{C}, \mathrm{P}}=3.1,{ }^{2} J_{\mathrm{C}, \mathrm{Pt}}=58.9, \mathrm{C}_{7}\right), 143.6\left(\mathrm{dd},{ }^{2} J_{\mathrm{C}, \mathrm{P} c i s}=5.6\right.$, $\left.{ }^{2} J_{\mathrm{C}, \mathrm{P} \text { trans }}=104.9, \mathrm{C}_{6}\right), 134.4\left(\mathrm{~d},{ }^{2} J_{\mathrm{C}, \mathrm{P}}=3.8,4 \mathrm{C}, \mathrm{Co}\right), 134.3\left(\mathrm{~d},{ }^{2} J_{\mathrm{C}, \mathrm{P}}=4.7\right.$, 4C, Co), 133.3-134.2 (m, 4C, $\mathrm{C}_{\mathrm{a}}, \mathrm{C}_{\mathrm{b}}, \mathrm{C}_{\mathrm{c}}$ and $\left.\mathrm{C}_{\mathrm{d}}\right), 132.9\left(\mathrm{~d},{ }^{4} J_{\mathrm{C}, \mathrm{P}}=2.3\right.$, $2 \mathrm{C}, \mathrm{C} p), 132.6\left(\mathrm{~d},{ }^{4} J_{\mathrm{C}, \mathrm{P}}=2.5,2 \mathrm{C}, \mathrm{C} p\right), 130.3\left(\mathrm{~d},{ }^{3} J_{\mathrm{C}, \mathrm{P}}=11.0,4 \mathrm{C}, \mathrm{Cm}\right)$, $129.8\left(\mathrm{~d},{ }^{3} J_{\mathrm{C}, \mathrm{P}}=11.4,4 \mathrm{C}, \mathrm{Cm}\right), 129.8\left(\mathrm{~d},{ }^{1} J_{\mathrm{P}, \mathrm{C}}=49.6,2 \mathrm{C}, \mathrm{Ci}\right), 129.2$ $\left(\mathrm{s}, \mathrm{C}_{9}\right), 128.8\left(\mathrm{dd},{ }^{4} J_{\mathrm{P}, \mathrm{C}}=7.0,{ }^{4} J_{\mathrm{P}, \mathrm{C}}=2.5, \mathrm{C}_{8}\right), 128.1\left(\mathrm{~d},{ }^{1} J_{\mathrm{P}, \mathrm{C}}=57.9,2 \mathrm{C}\right.$, $\mathrm{Ci}), 125.2\left(\mathrm{~d},{ }^{4} J_{\mathrm{C}, \mathrm{P}}=4.5,{ }^{3} J_{\mathrm{C}, \mathrm{Pt}}=29.2, \mathrm{C}_{3}\right), 116.9\left(\mathrm{~d},{ }^{4} J_{\mathrm{C}, \mathrm{P}}=2.3,{ }^{3} J_{\mathrm{C}, \mathrm{Pt}}=\right.$ 36.0, $\left.\mathrm{C}_{2}\right), 111.9\left(\mathrm{~d},{ }^{5} J_{\mathrm{C}, \mathrm{P}}=3.4,{ }^{4} J_{\mathrm{C}, \mathrm{Pt}}=25.0, \mathrm{C}_{10}\right), 61.0\left(\mathrm{~s}, \mathrm{CH}_{2}(\mathrm{OEt})\right)$, 39.3 (s, $\left.\mathrm{C}_{4}\right), 14.7$ (s, $\mathrm{CH}_{3}$ (OEt)). IR (ATR): $\nu=1717$ (m, C=O), 832, $548\left(\mathrm{~s}, \mathrm{PF}_{6}\right) \cdot \mathrm{MS}(\mathrm{MALDI}+): m / z(100) 870.1[\mathrm{M}]^{+} . \Lambda_{\mathrm{M}}\left(5 \times 10^{-4} \mathrm{M}\right.$ acetone solution): $67.8 \Omega^{-1} \mathrm{~cm}^{2} \mathrm{~mol}^{-1}$.

\section{Conflicts of interest}

There are no conflicts to declare.

\section{Acknowledgements}

This work was supported by the Spanish Ministerio de Economía y Competitividad (MINECO)/FEDER (Project CTQ2015-67461-P led by Dr Babil Menjón) and by the Gobierno de Aragón and Fondo Social Europeo (Grupo E17_17R: Química Inorgánica y de los Compuestos Organometálicos led by Dr José M. Casas). The authors thank the Instituto de Biocomputación y Física de Sistemas Complejos (BIFI) and Centro de Supercomputación de Galicia (CESGA) for generous allocation of computational resources. U. G. and C. B. acknowledge the support of Project I-Zeb, III Accordo Quadro CNR-Regione Lombardia. We acknowledge support of the publication fee by the CSIC Open Access Publication Support Initiative through its Unit of Information Resources for Research (URICI).

\section{References}

1 Y. C. Lin, M. Karlsson and M. Bettinelli, Top. Curr. Chem., 2016, 374, 21. 
2 E. Pavitra, G. S. R. Raju, J. Y. Park, L. Wang, B. K. Moon and J. S. Yu, Sci. Rep., 2015, 5, 10296.

3 J. Y. Tsao, M. E. Coltrin, M. H. Crawford and J. A. Simmons, Proc. IEEE, 2010, 98, 1162-1179.

4 M. Hatori, C. Gronfier, R. N. Van Gelder, P. S. Bernstein, J. Carreras, S. Panda, F. Marks, D. Sliney, C. E. Hunt, T. Hirota, T. Furukawa and K. Tsubota, npj Aging Mech. Dis., 2017, 3, 9.

5 T. A. LeGates, D. C. Fernandez and S. Hattar, Nat. Rev. Neurosci., 2014, 15, 443-454.

6 D. M. Berson, F. A. Dunn and M. Takao, Science, 2002, 295, 1070-1073.

7 F. Vienot, M. L. Durand and E. Mahler, J. Mod. Opt., 2009, 56, 1433-1446.

8 K. M. Zielinska-Dabkowska, Nature, 2018, 553, 274-276.

9 E. L. Zelinski, S. H. Deibel and R. J. McDonald, Neurosci. Biobehav. Rev., 2014, 40, 80-101.

10 C. La Morgia, F. N. Ross-Cisneros, A. A. Sadun and V. Carelli, Front. Neurol., 2017, 8, 1-8.

11 U. S. Department of Energy, U. S. Department of Energy, 2012, DOE/PI-0009.

12 C. L. Ho and W. Y. Wong, Top. Curr. Chem., 2016, 374.

13 A. F. Henwood and E. Zysman-Colman, Top. Curr. Chem., 2016, 374, 5 .

14 G. M. Farinola and R. Ragni, Chem. Soc. Rev., 2011, 40, 3467-3482.

15 C. Cebrian and M. Mauro, Beilstein J. Org. Chem., 2018, 14, 1459-1481.

16 M.-C. Tang, A. K.-W. Chan, M.-Y. Chan and V. W.-W. Yam, Top. Curr. Chem., 2016, 374, 1-43.

17 L. Murphy and J. A. G. Williams, Top. Organomet. Chem., 2010, 28, 75-111.

18 B. W. D'Andrade and S. R. Forrest, Adv. Mater., 2004, 16, 1585-1595.

19 T. Fleetham, J. Ecton, Z. Wang, N. Bakken and J. H. Li, Adv. Mater., 2013, 25, 2573-2576.

20 T. Fleetham, L. Huang and J. Li, Adv. Funct. Mater., 2014, 24, 6066-6073.

21 E. L. Williams, K. Haavisto, J. Li and G. E. Jabbour, Adv. Mater., 2007, 19, 197-202.

22 X. H. Yang, Z. X. Wang, S. Madakuni, J. Li and G. E. Jabbour, Adv. Mater., 2008, 20, 2405-2409.

23 G. Li, T. Fleetham and J. Li, Adv. Mater., 2014, 26, 2931-2936.

24 G. Cheng, P.-K. Chow, S. C. F. Kui, C.-C. Kwok and C.-M. Che, Adv. Mater., 2013, 25, 6765-6770.
25 S. Fuertes, H. Garcia, M. Peralvarez, W. Hertog, J. Carreras and V. Sicilia, Chem. - Eur. J., 2015, 21, 1620-1631.

26 S. Fuertes, A. J. Chueca, M. Perálvarez, P. Borja, M. Torrell, J. Carreras and V. Sicilia, ACS Appl. Mater. Interfaces, 2016, 8, 16160-16169.

27 S. Fuertes, A. J. Chueca, L. Arnal, A. Martín, U. Giovanella, C. Botta and V. Sicilia, Inorg. Chem., 2017, 56, 4829-4839.

28 P. E. Garrou, Chem. Rev., 1981, 81, 229-266.

29 L. Maidich, G. Zuri, S. Stoccoro, M. A. Cinellu and A. Zucca, Dalton Trans., 2014, 43, 14806-14815.

30 S. Fuertes, A. J. Chueca and V. Sicilia, Inorg. Chem., 2015, 54, 9885-9895.

31 J. A. G. Williams, Top. Curr. Chem., 2007, 281, 205-268.

32 Z. M. Hudson, C. Sun, M. G. Helander, Y. L. Chang, Z. H. Lu and S. N. Wang, J. Am. Chem. Soc., 2012, 134, 13930-13933.

33 Y. Unger, D. Meyer, O. Molt, C. Schildknecht, I. Münster, G. Wagenblast and T. Strassner, Angew. Chem., Int. Ed., 2010, 49, 10214-10216.

34 T. Fleetham, Z. Wang and J. Li, Org. Electron., 2012, 13, 1430-1435.

35 X.-C. Hang, T. Fleetham, E. Turner, J. Brooks and J. Li, Angew. Chem., Int. Ed., 2013, 52, 6753-6756.

36 K. Hayashi, H. Nakanotani, M. Inoue, K. Yoshida, O. Mikhnenko, T.-Q. Nguyen and C. Adachi, Appl. Phys. Lett., 2015, 106, 093301.

37 N. C. Giebink and S. R. Forrest, Phys. Rev. B: Condens. Matter Mater. Phys., 2008, 77, 235215.

38 J. Fornies, V. Sicilia, P. Borja, J. M. Casas, A. Diez, E. Lalinde, C. Larraz, A. Martin and M. T. Moreno, Chem - Asian J., 2012, 7, 2813-2823.

39 T. W. Murphy, J. Appl. Phys., 2012, 111, 104909.

40 A. Zabiliute, R. Vaicekauskas, P. Vitta and A. Zukauskas, Opt. Lett., 2014, 39, 563-566.

41 A. C78.374-2015, Light-Emitting Diode Package Specification Sheet for General Illumination Applications.

42 L. Y. Wang, E. H. Song, Y. Y. Zhou, T. T. Deng, S. Ye and Q. Y. Zhang, J. Mater. Chem. C, 2018, 6, 8670-8678.

43 W. L. Zhou, M. H. Fang, S. X. Lian and R. S. Liu, ACS Appl. Mater. Interfaces, 2018, 10, 17508-17511.

44 C. F. Lai, J. S. Li and C. W. Shen, ACS Appl. Mater. Interfaces, 2017, 9, 4851-4859.

45 W. J. Zhou, M. Gu, Y. Y. Ou, C. H. Zhang, X. J. Zhang, L. Zhou and H. B. Liang, Inorg. Chem., 2017, 56, 7433-7442.

46 H. M. Zhu, C. C. Lin, W. Q. Luo, S. T. Shu, Z. G. Liu, Y. S. Liu, J. T. Kong, E. Ma, Y. G. Cao, R. S. Liu and X. Y. Chen, Nat. Commun., 2014, 5, 4312. 